\title{
Constitución, Estatutos de Autonomía y Gobierno Local \\ Claves para una lectura constitucionalmente óptima de la autonomía local
}

\author{
Octavio Salazar Benítez \\ Profesor Titular de Derecho Constitucional \\ Universidad de Córdoba
}

Sumario: I. INTRODUCCIÓN: LA AUTONOMÍA LOCAL EN SERIO. - II. EL CARÁCTER POLÍTICO DE LA AUTONOMÍA LOCAL. - III. EL CARÁCTER BIFRONTE DEL RÉGIMEN LOCAL. - IV. LA INTERIORIZACIÓN DEL RÉGIMEN LOCAL EN LOS ESTATUTOS DE AUTONOMÍA. 1. Asunción de la competencia sobre régimen local. 2. Organización territorial y competencias de los gobiernos locales. 3. Principios de la organización territorial. 4. Las comarcas y otras agrupaciones de municipios. 5. Las provincias. 6. Órganos de relación entre los entes locales y las Comunidades Autónomas. 7. La financiación de los entes locales.V. CONCLUSIONES.

\section{INTRODUCCIÓN: LA AUTONOMÍA LOCAL EN SERIO}

Durante los treinta años de vigencia de la Constitución Española, el debate político y científico en torno a la estructura territorial del Estado se ha centrado en el derecho a la autonomía de las nacionalidades y regiones ${ }^{1}$. Todavía hoy, la atención continúa girando en torno a un hipotético «cierre» del proceso autonómico a través de las reformas estatutarias iniciadas en los últimos años y de la poco probable, aunque necesaria, reforma del texto constitucional. De hecho, las reformas de los Estatutos autonómicos aprobadas en la VIII legislatura incidieron de manera notable en la autonomía local y, sin embargo, no llegó a debatirse en las Cortes el proyecto de reforma de la ley básica de gobierno local preparado por el Ministerio de Administraciones Públicas (en adelante, Anteproyecto LBGAL) ${ }^{2}$. Una vez más, las Comunidades Autónomas centralizaron

\footnotetext{
1 Como bien ha explicado Francisco CAAMAÑo DomínguEZ, la descentralización prevista en la Constitución se entendió durante años como una «cosa de dos (Estado y Comunidades Autónomas)» y, de hecho, hasta que se cerró el mapa autonómico no se aprobó la ley que adaptaba las entidades locales a las exigencias constitucionales. La Ley Reguladora de las Bases de Régimen Local de 1985 fue, en todo caso, una ley continuista, tremendamente uniformizadora y careció de un debate en profundidad sobre el gobierno local. Además hubo que esperar tres años más para que se aprobara una Ley de Haciendas Locales. «Autonomía local y Constitución. Dos propuestas para otro viaje por el callejón del gato», Revista Española de Derecho Constitucional. N. ${ }^{\circ}$ 70, enero-abril 2004. Págs. 162-163.

2 Este proyecto fue a su vez precedido del denominado Libro blanco sobre la reforma del gobierno local (en adelante, Libro Blanco), elaborado por una Comisión que con tal objetivo se creó por Orden de 27 de julio de 2004. Esta Comisión aportó un primer borrador en enero de 2005 y el texto definitivo en julio de ese
} 
toda la atención política mientras que la reforma del régimen local se desvanecía a la espera de «tiempos mejores». Es previsible que en la actual legislatura el gobierno retome el proyecto, ya que así se planteaba al menos en el programa electoral del $\mathrm{PSOE}^{3}$, si bien es cierto que el proceso nacerá «herido» jurídicamente en la medida en que, como reiteradamente ha sucedido en la construcción del Estado autonómico, se ha obviado la debida coordinación entre el Estado, las Comunidades Autónomas y las entidades locales ${ }^{4}$.

Durante la mayor parte de estos 30 años de andadura constitucional, la fundamental contribución de las entidades locales a la vertebración democrática de nuestro país no ha tenido un paralelo reconocimiento de su esencialidad en la estructura territorial del Estado. Sólo a partir de la década de los noventa empezó a quebrarse esa tendencia gracias a las reivindicaciones de las distintas federaciones de municipios y provincias - en especial, de la española ${ }^{5}$ - y a las

mismo año. A lo largo del texto iré haciendo referencia tanto al Anteproyecto de Ley como al Libro Blanco. He consultado ambos en la página web del Ministerio de Administraciones Públicas (www.map.es, 20 de noviembre de 2007).

3 En concreto, el programa electoral del PSOE para las elecciones generales de marzo de 2008 incluía el impulso de «una nueva legislación de Bases del Régimen Local, un nuevo Gobierno y una reforma de la Financiación Local». También el PP incluía en su programa la reforma del «régimen local básico». Ambos partidos proponían a su vez una serie de reformas más concretas. Por ejemplo, el PSOE insistía en el impulso de la cooperación y del diálogo entre Ayuntamientos, Comunidades Autónomas y Administración central, proponiendo medidas concretas como la participación de los Municipios en las conferencias sectoriales del Estado. También proponía una nueva organización y funcionamiento de la democracia municipal (estructuras de participación, Estatuto del concejal, Carta de derechos y deberes ciudadanos), el apoyo a los pequeños municipios, la promoción de la intermunicipalidad y de un nuevo gobierno de la provincia, la mejora de la financiación y el impulso de unos Ayuntamientos «innovadores» (Ley de acceso electrónico a los servicios públicos, gobierno electrónico, sistemas de quejas y sugerencias). De manera similar, el PP insistía en revisar la financiación de las corporaciones locales y en impulsar el Estatuto del Gobierno Local como norma básica del marco institucional y competencial de las administraciones locales. Más concretamente proponía la celebración de dos debates de política local cada legislatura en el Senado o la institucionalización de la FEMP como órgano representativo de los intereses de los entes locales. Además reiteraba una reivindicación mantenida desde hace años por este partido: la reforma de la Ley electoral para garantizar que el ayuntamiento sea gobernado por la candidatura más votada.

4 A esos proyectos habría que añadir que en noviembre de 2004, coincidiendo con el Foro de ciudades que se celebró para conmemorar los 25 años de ayuntamientos democráticos, se aprobó la denominada «Carta de Vitoria» en la que se contiene el decálogo que debería presidir el municipalismo del siglo XXI. En concreto, la Carta marca los siguientes objetivos: garantizar la representación de los poderes locales en el Senado, aprobar un nuevo Estatuto del gobierno local, lograr un gobierno local solvente y de proximidad, reforzar los mecanismos de relaciones intergubernamentales, conseguir un nuevo régimen de organización para los gobierno locales, un estatuto de los cargos electos locales, la modernización de la función pública local, la institucionalización de la FEMP y el reconocimiento de los poderes locales como órganos de gestión e instituciones públicas.

5 La propuesta de reforma planteada por la FEMP, conocida como «Pacto Local», se concretó en un total de 92 medidas que fueron aprobadas por su Comisión Ejecutiva el 24 de septiembre de 1996. Como resultado de dichas reivindicaciones se llevaron a cabo en 1999 una serie de reformas legislativas que, sin embargo, dejaron sin resolver las cuestiones más importantes: la definición del ámbito competencial de los municipios y su financiación. Las reformas más significativas afectaron a la LRBRL (mediante la Ley 11/99, de 21 de abril, se ampliaron las atribuciones de los Alcaldes y se potenciaron los mecanismos de control del Pleno), a la LOTC (mediante la Ley 7/99, de 21 de abril, se introdujo el denominado «conflicto en defensa de la autonomía local») y a la LOREG (mediante la LO 8/99, de 21 de abril, se introdujeron más restricciones para la 
reflexiones de un importante sector doctrinal que desde distintos ámbitos - el Derecho Público, la Sociología, la Ciencia Política - comenzó a insistir en la importancia del gobierno local. Sin embargo, y a pesar de esta atención creciente, la autonomía local no ha sido una materia especialmente abordada por los constitucionalistas. El régimen local ha sido preferentemente analizado desde el Derecho Administrativo, lo cual ha contribuido a mantener una cierta debilidad de su dimensión político-constitucional ${ }^{6}$.

Alcanzados los treinta años de vigencia de la Constitución, es necesario que desde el Derecho Constitucional nos tomemos la autonomía local en serio y abordemos el lugar que le corresponde en la estructura territorial del Estado. Dos argumentos avalan la oportunidad de esta reflexión. De una parte, el debate planteado en torno a las recientes reformas estatutarias, en las que se ha producido un significativo avance en la «interiorización» autonómica del régimen local, es una buena oportunidad para dotar de contenido a la autonomía local y, sobre todo, para aclarar su posición en relación al Estado y a las Comunidades Autónomas. De otra parte, estas reflexiones deben plantearse en un contexto en el que, de manera paralela a los fenómenos de internacionalización, no ha dejado de crecer el protagonismo de las ciudades ${ }^{7}$, convertidas en espacios estratégicos desde los que es posibles contrarrestar las amenazas que conlleva el proceso de globalización o los riesgos que implica la crisis de un modelo de Estado que ha visto adelgazar progresivamente su compromiso social. De hecho, los Ayuntamientos han cumplido en los últimos años un papel primordial en la corrección de desequilibrios y carencias sociales, en muchos casos sin un título competencial que respaldase dichas actuaciones y, lo que es más grave, sin una financiación capaz de sostener una serie de prestaciones y servicios que inciden de manera inmediata en el bienestar y en la calidad de vida de la vecindad ${ }^{8}$. Piénsese por ejemplo en todas las actuaciones que los Ayuntamientos están realizando en los últimos años en materia de inmigración ${ }^{9}$. Ello ha provocado, entre otras consecuencias, un importante endeudamiento de las corporaciones locales, en el cual ha estado a su vez el origen de

convocatoria y celebración de mociones de censura, así como la cuestión de confianza). Véase José Manuel RoDríGueZ ÁlvareZ, La Reforma del Régimen Local de 1999. Las medidas legislativas estatales en el marco del Pacto Local. Bayer Hermanos. Barcelona, 1999.

6 Joaquín GARCÍA MORILLO apuntó en su momento tres razones que podían explicar la poca atención prestada por el Derecho Constitucional a la autonomía local: el papel secundario que las instituciones locales han desempeñado históricamente, la parquedad de la regulación constitucional de los entes locales y la considerable heterogeneidad que la configuración de los entes locales reviste en los distintos ordenamientos. La configuración constitucional de la autonomía local. Marcial Pons. Diputació de Barcelona, 1998. Págs. 18-19.

7 Francisco Velasco Caballero, «El estado de la autonomía local en 2007», Anuario de Derecho Municipal 2007. Págs. 21-22. Sobre este tema véase Jordi BORJA y Manuel CASTELLS, Lo local y lo global. La gestión de las ciudades en la era de la información. Taurus. Madrid, 1992.

8 En este sentido se ha llegado a hablar de «municipio de bienestar». Ismael BLANCO y Ricard GomA (coords.), Gobiernos locales y redes participativas. Ariel. Barcelona, 2002.

9 Sobre este tema véase por ejemplo Eduardo ORTEGA MARín, «Efectos de la inmigración sobre las competencias locales y la vida cotidiana», Cuadernos de Derecho Local. N. ${ }^{\circ}$ 6, octubre de 2004. Págs. 40-46. 
muchas de las situaciones de corrupción que han sacudido recientemente la vida municipal española.

Junto a todos estos factores, no podemos olvidar que el local es el espacio en el que, dadas sus dimensiones, es posible articular un sistema de gobierno en el que, al menos parcialmente, se compensen los «excesos» de la democracia de partidos. De hecho, en las dos últimas décadas se ha desarrollado una abundante literatura en torno a la participación ciudadana así como sobre la necesidad de articular una nueva gobernanza local caracterizada por la interacción permanente entre los poderes públicos y los agentes sociales ${ }^{10}$.

En este contexto debemos abordar los tres grandes retos pendientes de nuestro régimen local: su posición en el Estado autonómico, con la consiguiente delimitación de su ámbito competencial; la adaptación de sus estructuras de gobierno a la creciente diversidad y complejidad de la acción política local y, de manera prioritaria, pues sin ella quedarían en el aire las dos anteriores, la mejora de una financiación claramente insuficiente para sostener todas las políticas públicas que las Corporaciones locales han ido asumiendo en las últimas décadas. Todo ello deberá repercutir en una mejor articulación de los tres niveles territoriales de nuestro sistema constitucional y en la superación de la situación de provisionalidad que la autonomía local mantiene desde hace tres décadas en nuestro país.

\section{EL CARÁCTER POLÍTICO DE LA AUTONOMÍA LOCAL}

El Título VIII CE comienza proclamando en el art. 137 los tres ámbitos territoriales autónomos en los que se organiza el Estado español - los municipios, las provincias y las Comunidades Autónomas - los cuales «gozan de autonomía para la gestión de sus respectivos intereses». Tal y como reconociera el Tribunal Constitucional en su sentencia de 2 de febrero de 1981, dicho artículo «refleja una concepción amplia y compleja del Estado, compuesto por una pluralidad de organizaciones de carácter territorial, dotadas de autonomía», las cuales constituyen «elementos arquitecturales indispensables del orden constitucional» ${ }^{11}$. Por lo tanto, las entidades locales son, en los mismos térmi-

\footnotetext{
10 Como bien ha explicado Luis MORELL, «la Administración Local, por su cercanía, por su inmediatividad respecto del ciudadano medio, ni es ni puede ser un poder lejano y extraño a nosotros mismos, sino una organización de la que formemos parte ella, a su vez, forme parte de lo que es genuina y peculiarmente nuestro. De ahí que la Administración local sea la esfera de poder que más fácilmente pueda identificarse con el ciudadano medio; y, por ello, está destinada a dar la versión más «humanista» posible del fenómeno administrativo». Luis MoREll OCAÑA, «La autonomía local», Revista General de Derecho Administrativo. N . 13 , septiembre 2006. Pág. 29 (consultada a través de www.iustel.com, 24-11-2008). Sobre la «gobernanza» local, véase Juan-Cruz Allí ARANGUREN, «La gobernanza local», Revista de Estudios de la Administración Local y Autonómica. N. $^{\circ} 291$, enero-abril 2003.

11 Como bien ha señalado Javier GARCÍA ROCA, «debe revalorizarse la importancia de este artículo, ya que es el dintel de todo el Título VIII, la norma que fija el basamento en el que el resto de las disposiciones cons-
} 
nos que las Comunidades autónomas, elementos de la organización territorial del Estado. Ambos niveles territoriales poseen una autonomía de la misma naturaleza y sólo difieren en el alcance y en la distinta capacidad de configuración social que les ha otorgado el constituyente ${ }^{12}$. Por lo tanto, no cabe considerar a las Corporaciones locales como escalones jerárquicamente subordinados a las Comunidades Autónomas: «también... expresan soberanía en su ámbito autónomo de poder. No es la Ley la que le atribuye a los Entes locales la expresión de esta soberanía, sino la propia Constitución. La ley la delimita, pero es la Constitución quien la reconoce» ${ }^{13}$.

La Constitución de 1978 ofrece escasos elementos para la definición de la autonomía local. No obstante, de los tres artículos que componen el capítulo II del título VIII pueden deducirse los siguientes principios de nuestro régimen local ${ }^{14}:$. La condición de los Municipios como entes públicos y territoriales que integran el Estado ordenamiento, dotados de autonomía (arts. 137 y 140) y de medios suficientes para el desempeño de sus funciones mediante tributos propios y la participación en los del Estado y las Comunidades Autónomas (art. 142); 2. La consagración del pluralismo territorial como valor (art. 137), sumada a la función de defensa del interés local del gobierno y administración locales (art. 140); 3. La ordenación de ese gobierno conforme al principio democrático representativo (art. 140 y 141) ${ }^{15}$.

Estos principios deben ser completados e interpretados de acuerdo con las previsiones de la Carta Europea de Autonomía Local (en adelante, CEAL) ${ }^{16}$.

\footnotetext{
titucionales deben comprenderse antes de ser interpretadas». Javier GARCíA ROCA, «El concepto actual de autonomía local según el bloque de la constitucionalidad», Revista de Estudios de la Administración Local y Autonómica. N. $^{\circ}$ 282, enero-abril 2000. Pág. 27.

12 Luciano Parejo Alfonso, «La autonomía local en la Constitución», Tratado de Derecho Municipal (S. MuÑOZ MACHADO, dir.), vol. I. Civitas. Madrid, 1998. Págs. 40-41.

13 Luis ORTEGA, «La potestad normativa local», Anuario de Gobierno Local, 2001. Pág. 41.

14 Javier GARCía ROCA, «El concepto actual de autonomía local según el bloque de constitucionalidad», cit. Pág. 34.

15 Junto a dichos principios habría que tener en cuenta la distinción entre la autonomía municipal y la provincial. La primera puede calificarse como reforzada frente a la limitada o relativizable de las provincias. Esta diferencia se apoya en dos elementos: por una parte, para la Constitución la provincia es una entidad local de segundo nivel; por otra, la vigencia del principio democrático en ambos tipos de entes es bien distinta. Francisco Velasco Caballero, «Autonomía local y subsidiariedad en la reforma de los Estatutos de autonomía», Anuario de Gobierno Local, 2004. pág. 126.

16 En el marco normativo de la Unión Europea sólo encontramos mínimas referencias a la autonomía local. El Tratado de Lisboa, firmado el 13 de diciembre de 2007, se limita a reproducir en el nuevo art. 4.2 lo que ya preveía el proyecto de la Constitución europea: «La Unión respetará la igualdad de los Estados miembros ante los tratados así como su identidad nacional, inherente las estructurales fundamentales políticas y constitucionales de estos, también en lo referente a la autonomía local y regional...». A esta referencia habría que sumar la relativa al principio de subsidiariedad: «En virtud del principio de subsidiariedad, en los ámbitos que no sean de su competencia exclusiva, la Unión intervendrá sólo en caso de que, y en la medida en que, los objetivos de la acción pretendida no puedan ser alcanzados de manera suficiente por los Estados miembros, ni a nivel central ni a nivel regional y local, sino que puedan alcanzarse mejor, debido a la dimensión o a los efectos de la acción pretendida, a escala de la Unión».
} 
Esta Carta, firmada en Estrasburgo el 15 de octubre de 1985 y ratificada por nuestro país el 20 de enero de 1988, entró en vigor el 1 de marzo de $1989 .{ }^{17} \mathrm{La}$ Constitución, los Estatutos de Autonomía, la Ley de Bases de Régimen Local y la legislación sectorial atributiva de competencias a los entes locales deben ser interpretados de acuerdo con ella ${ }^{18}$. Como bien ha explicado Javier García Roca, «la CEAL cierra los espacios abiertos en la Constitución y obliga a interpretar las disposiciones constitucionales de principios desde los criterios hermenéuticos que ella misma enuncia. Esa eficacia informadora se produce praeter y secundum Constitutionem: bien en defecto de previsiones constitucionales expresas bien de forma complementaria de las mismas» ${ }^{19}$.

La CEAL contienen una serie de principios que nos deben servir como «hoja de ruta» en las necesarias reformas que demanda este escalón territorial. La definición que de autonomía local nos ofrece su artículo 3 («el derecho y la capacidad efectiva de las Entidades locales de ordenar y gestionar una parte importante de los asuntos públicos, en el marco de la ley, bajo su propia responsabilidad y en beneficio de sus habitantes» $)^{20}$ debe conectarse con los principios de subsidiariedad («el ejercicio de las competencias públicas debe, de modo general, incumbir preferentemente a las autoridades más cercanas a los ciudadanos. La atribución de una competencia a otra autoridad debe tener en cuenta la amplitud o la naturaleza de la tarea o las necesidades de eficacia y economía», art. 4.3 CEAL) y democrático (el art. 3.2 CEAL exige que la autonomía local se ejerza por Asambleas o consejos integrados por miembros elegidos por sufragio universal y establece la posibilidad de que dispongan de ejecutivos que respondan ante los mismos, lo cual no impedirá el recurso a las asambleas de vecinos, al referéndum o a cualquier otra forma de participación

17 Sobre la Carta Europea de Autonomía Local, véase Joaquín ToRnOs MÁs, «Por un sistema de control de la Carta Europea de la Autonomía Local», Revista de Estudios de la Administración Local y Autonómica. N. ${ }^{\mathrm{a}}$ 255-256, julio-diciembre 1992. Págs. 818-825; Luis ORTEGA ÁlvarEZ, «La Carta Europea de Autonomía Local y el ordenamiento local español», Revista de Estudios de la Administración Local y Autonómica, n. ${ }^{\circ}$ 259, julio-septiembre 1993. Págs. 475 ss.

18 Ello permitirá desarrollar al máximo posible la autonomía local y satisfacer por tanto el «mandato de optimización» que los arts. 137, 140 y 141 CE imponen a los poderes públicos. Francisco VELASCO CABALLERO, «Estatutos de autonomía, leyes básicas y leyes autonómicas en el sistema de fuentes del Derecho local», Anuario de Gobierno Local 2006. Pág. 129.

19 Javier GARCÍA ROCA, «Un bloque constitucional local conforme al principio de subsidiariedad (desarro1lo constitucional pendiente)», Revista de Estudios de la Administración Local y Autonómica. N. ${ }^{\circ} 294-295$, 2004. Pág. 35. En este sentido, cabe destacar como el nuevo Estatuto andaluz (LO 2/2007) ha incorporado expresamente esta norma internacional al concretar los principios que deben regir las relaciones entre la Administración de la Comunidad autónoma y las Administraciones locales, las cuales deberán observar «la garantía institucional de la autonomía local reconocida por la Constitución y por la Carta Europea de la Autonomía local» (art. 89.2). También hace referencia a la CEAL el Estatuto Valenciano al referirse al principio de subsidiariedad como uno de los rectores en la distribución de responsabilidades entre las diversas administraciones locales (art. 64.2). «Esta «estatutorización» de una norma internacional puede resultar útil para dotar de una eficacia cuasiconstitucional a la CEAL. Esto es, para que la Carta Europea sirva de canon (mediato) de constitucionalidad ante las leyes autonómicas». Francisco VELASCO, «El estado de la autonomía local en 2007», cit. Págs. 26-27.

20 El Anteproyecto LBGAL incorporaba de manera literal esta definición de autonomía local en su art. 2.2. 
directa de los ciudadanos, allí donde esté permitido por la Ley). Tres principios que dejan de tener sentido si, contradiciendo el art. 4.4 CEAL, las competencias encomendadas a las entidades locales no son plenas y completas. La suma de estos principios ha de confluir en el «entendimiento de la autonomía local como una potestad universal de actuación pública preferente, políticamente responsable y constitucionalmente garantizada», la cual «supondría la inconstitucionalidad de todo intento legal por desapoderar a los entes locales para llevar a cabo todas aquellas iniciativas públicos o servicios que voluntariamente hubiesen decidido acometer, alegando carencia de título legal habilitante o invasión de competencias ajenas» ${ }^{21}$. En este sentido debe interpretarse el art. 25.1 LRBRL, según el cual «el municipio, para la gestión de sus intereses y en el ámbito de sus competencias, puede promover toda clase de actividades y prestar cuantos servicios públicos contribuyan a satisfacer las necesidades y aspiraciones de la comunidad vecinal». De este artículo podemos deducir, tal y como subrayó el Libro Blanco, un derecho a la espontaneidad del gobierno local para dar respuesta a las demandas ciudadanas, una presunción de competencia universal derivada de la garantía constitucional de la autonomía local ${ }^{22}$.

Lo que a estas alturas debe estar fuera de toda duda, tal y como subrayan los principios comentados, es el carácter inequívocamente político de la autonomía local, a pesar de que han sido muchas las páginas, sobre todo procedentes de administrativistas, que han cuestionado dicha caracterización ${ }^{23}$. Buena parte de estas reflexiones se han hecho sobre la diferenciación del grado de autonomía que poseen los entes locales y las Comunidades Autónomas, confirmada por el mismo TC en su primera jurisprudencia. Así la STC 25/81, de 14 de julio, reconoció que las Comunidades Autónomas gozaban «de una autonomía cualitativamente superior a la administrativa que corresponde a los entes locales, ya que se añaden potestades legislativas y gubernamentales que la configuran como

\footnotetext{
21 Francisco CAAmaño DomíngueZ, «Autonomía local y Constitución...», cit. Pág. 181.

22 «Dicha «universalidad de su círculo de acción», expresiva de la existencia de una presunción de competencia beneficiándoles, implica, a su vez, un «derecho de apropiación» o de «descubrimiento de nuevas tareas», por parte de los mismos, lo que, rectamente entendido, ha de suponer que el legislador deberá abstenerse de ocupar efectivamente tal área, a fin de desplazar sus contenidos a otra u otras instancias territoriales de gobierno, a menos que demuestre que existe un interés público preferente así aconsejándolo. En todo caso, deberá asumir la carga de la prueba». José M. ${ }^{a}$ PORRAS RAMíREZ, « El autogobierno local en el Estado autonómico. Premisas para una reforma necesaria», Revista Española de Derecho Constitucional. N. ${ }^{\circ} 75$, septiembre-diciembre 2005. Pág. 221.
}

23 Sirva como ejemplo la opinión de Luis MORELL OCAÑA, quien afirma que «Los Municipios y Provincias con las Islas constituyen la Administración Local. Su autonomía no es política, como la de las Comunidades Autónomas, sino meramente administrativa». «La Administración Local en la Constitución», en VV.AA., Administraciones Públicas y Constitución. INAP. Madrid, 1998. Pág. 785.

Todavía en fechas muy recientes Luciano PAREJO ALFONSO se contradecía en un mismo párrafo en el que empezaba hablando de que la autonomía local era «indudablemente» administrativa, para afirmar a continuación que es «consustancial al poder-ordenamiento local la capacidad creativa, es decir, la de elegir entre alternativas según opciones propias y, por tanto, de formulación y ejecución de las políticas correspondientes...». «Una visión sobre el gobierno local», Anuario de Gobierno Local, 2004. Pág. 56. 
autonomía de naturaleza política» ${ }^{24}$. El elemento clave estaría pues en la posesión o no de potestad legislativa, pues también los entes locales tienen potestades gubernamentales ya que la propia Constitución atribuye a los Ayuntamientos «el gobierno y la Administración de los municipios» (art. 140).

Pese a esa jurisprudencia, y a la doctrina que la sigue reafirmando, es imposible negar el carácter político de la autonomía local. No podemos desconocer que en los municipios existe «un cierto «componente político»..., siendo precisamente ese componente político el motor de la vida municipal y cuyo respeto en cierta manera garantiza la Constitución, no pudiendo ser desconocido por el Estado en ningún caso, y sólo por razones de defensa de los intereses nacionales que le están encomendados podrá el poder del Estado limitar dicha iniciativa municipal, sin que sea admisible en la actualidad cualquier otro control patrocinado por razones de tutela o estructura jerárquica...» (STS de 3 de febrero de 1987). La «inequívoca sustancia política de las entidades locales» se traduce en una «dirección política propia, potestad normativa primaria, competencias definidas y atinentes al interés local, autonomía financiera o de gasto - más que de ingreso - , autonomía funcionarial, un gobierno representativo de los vecinos que encabeza la Administración local, y responsabilidad política ante el electorado» ${ }^{25}$. Incluso si nos fijamos en la capacidad de ordenación mediante leyes, tampoco deberíamos olvidar que también los Ayuntamientos pueden dictar normas que, si bien no pueden denominarse leyes y han de actuar dentro del marco restringido que permite la autonomía local, han sido establecidas por un órgano representativo elegido por los veci$\operatorname{nos}^{26}$. De ahí que la vinculación de los reglamentos locales con las leyes estatales o autonómicas haya de entenderse como negativa ${ }^{27}$. El ente local podrá

24 Como bien ha señalado Francisco CAAMAÑo DomíngUEZ, el TC llevó a cabo, mediante una jurisprudencia en la que se limitó a declarar lo que la autonomía local no era, una reafirmación de la autonomía de las Comunidades Autónomas. «Autonomía local y Constitución: Dos propuestas para otro viaje por el callejón del gato», cit. Págs. 165-166.

25 Javier GARCÍA ROCA, «El concepto actual de autonomía local...», cit. Pág. 52.

26 En este sentido, y como ha llegado a afirmar Luciano PAREJO ALFONSO, «la Ordenanza es la ley en la economía interna del ordenamiento local». «La autonomía local en la Constitución», cit. Pág. 40. En un sentido similar, Javier GARCÍA ROCA nos recuerda que la singularidad como fuente del Derecho de la potestad normativa local: «Las relaciones de complementariedad y ejecución entre la potestad reglamentaria del Gobierno y la potestad legislativa del Parlamento, ambas fuentes de órganos ubicados dentro de un mismo ente territorial (el Estado o la CA), y copartícipes de una misma dirección política, o el intenso alcance vinculatorio del principio de legalidad, no pueden predicarse con idéntico tenor de las relaciones entre potestad legislativa estatal o autonómica y la potestad reglamentaria de unas entidades locales dotadas de autonomía política». «El nuevo conflicto en defensa de la autonomía local», Justicia Administrativa. N. ${ }^{\circ}$ extraordinario 2000 sobre «La reforma del régimen local», cit. Pág. 12. En este sentido, el Libro Blanco para la Reforma del Gobierno local caracterizaba la ordenanza como «norma sustantiva que articula una decisión política». Sobre la potestad normativa local véanse Luciano PAREJO, La potestad normativa local. Marcial Pons. Madrid, 1998 y José Luis Blasco DíAZ, Ordenanza municipal y ley. Marcial Pons. Madrid, 2001.

27 Esa vinculación «negativa» a la ley fue reconocida inicialmente por el Consejo de Estado (Dictamen n. ${ }^{\circ}$ 1749, de 23 de febrero de 1995), el cual se apoyó en el art. 55 del Texto Refundido de Régimen Local de 1986 en el que se dice que las ordenanzas «en ningún caso contendrán preceptos opuestos a las leyes». Posteriormente esa relación de las normas municipales con las ley fue reconocida por el Tribunal Constitu- 
regular todo aquello que no le esté vedado por la ley. De lo contrario, estaríamos negando su autonomía política. Por lo tanto, cuando se caracteriza la autonomía local como «autonomía en el marco de la ley» no se está negando una capacidad creativa propia. Lo que se está señalando es que, dentro de los márgenes señalados por el legislador, existe un espacio para gestionar los intereses locales de acuerdo con un determinado programa político. Es decir, existen, y en todo caso deben garantizarse, determinados espacios de discrecionalidad política $^{28}$. Por otra parte, no podemos olvidar que la actividad política institucionalizada no sólo se expresa a través de la creación de normas: «lo esencial es la correspondencia entre la voluntad colectiva de una comunidad identificada por el dato básico de su convivencia en un mismo territorio, es decir, la de los ciudadanos que componen en cuanto tales, y la acción pública de las organizaciones representativas de los mismos que tienen encomendada la gestión de una parte de sus intereses» ${ }^{29}$.

En definitiva, el carácter político de la autonomía local deriva de la conexión entre los principios de autonomía y democrático, tal y como se desprende del art. $3 \mathrm{CEAL}^{30}$. Es decir, el pluralismo político se concreta en la configuración de un órgano legitimado democráticamente, con capacidad para adoptar decisiones propias e independientes con respecto a otros entes de categoría superior, así como para ejecutarlas. La autonomía local vendría así definida por la «capacidad de dirección (indirizzo) política-administrativa de sus titulares, siguiendo el concepto clásico dado por Massimo Severo Giannini ${ }^{31}$. Existe, por tanto, una acción de gobierno o una función de dirección política local. La capacidad de «dirección política» se halla implícita en la atribución del gobierno y la administración que el art. 140 CE realiza a los Ayuntamientos y el art. 141 CE a las Diputaciones, así como en varios artículos de la LRBRL como el 1, el cual reconoce al municipio «plena capacidad para el cumplimiento de sus fines» o el ya citado artículo 25 .

\footnotetext{
cional en su sentencia 233/1989, de 16 de diciembre, relativa a la Ley de Haciendas Locales, y mantenida en pronunciamientos posteriores como los de las sentencias 106/2000, de 4 de mayo y 132/2001, de 8 de junio. El legislador plasmó esta doctrina en el Título XI añadido a la LRBRL por la Ley 57/2003, dedicado a la «Tipificación de las infracciones y sanciones por las Entidades locales en determinadas materias». En concreto, el art. 139 LRBRL dispone que «para la adecuada ordenación de las relaciones de convivencia de interés local y del uso de sus equipamientos, infraestructuras, instalaciones y espacios públicos, los entes locales podrán, en defecto de normativa sectorial específica, establecer los tipos de infracciones e imponer sanciones por el incumplimiento de deberes, prohibiciones o limitaciones contenidos en las correspondientes ordenanzas,...».

28 Joan BARATA i Mir, Los actos de gobierno en el ámbito municipal. Tecnos. Madrid, 1999. Págs. 75-76.

29 Miguel SÁNCHEZ MoRón, La autonomía local. Antecedentes históricos y significado constitucional. Civitas. Universidad Complutense. Madrid, 1990. Pág. 175.

30 La conexión entre el principio de «autonomía» y el «democrático» era evidente en la definición de municipio que contenía el Anteproyecto LBGAL en su art. 1.2: «El municipio es la entidad local básica de la organización territorial del Estado, instancia de representación política y cauce inmediato de participación ciudadana en los asuntos públicos».
}

31 Massimo Severo Giannini, Diritto Amministrativo. Vol I. Giuffrè. Milano, 1970. Pág. 176. 
Este carácter de las entidades locales excluye la dependencia jerárquica y cualquier control de oportunidad política sobre ellas. La base representativa democrática del municipio implica la responsabilidad de la corporación local ante el electorado, no ante el Gobierno del Estado ni ante ningún órgano de las CC.AA. Así lo dejó claro el TC desde un primer momento, al excluir los «controles genéricos e indeterminados que sitúen a las entidades locales en una posición de subordinación o dependencia cuasi jerárquica de la administración del Estado u otras entidades territoriales» (STC 4/81). Sólo cabrían pues controles de legalidad (SSTC 4/81, 46/92, 11/99). En este sentido hay que entender los controles que la LRBRL prevé en el capítulo III de su Título V dedicado a la «Impugnación de actos y acuerdos y ejercicio de acciones» ${ }^{32}$.

Sin embargo, y a pesar de todas estas previsiones, nuestro sistema constitucional se ha caracterizado a lo largo de estos años por una débil garantía de la autonomía local, en muchos casos por su misma indefinición, en otros por la presencia abrumadora tanto del Estado como de las Comunidades Autónomas, todo ello sin contar con las insuficiencias financieras que han condicionado el desarrollo de políticas locales propias. Algo a lo que durante décadas ha ayudado el entendimiento de la «autonomía local» desde la categoría de la «garantía institucional», formulada por el TC en su sentencia 32/81. Esta técnica, cada vez menos usada por la doctrina aunque todavía presente en los pronunciamientos del $\mathrm{TC}^{33}$, ha servido para cumplir una función defensiva o negativa pero no ha permitido consolidar una dimensión positiva de dicha autonomía ${ }^{34}$. De ahí que consideremos preferible hablar, como lo ha venido haciendo un sector doctrinal, de «garantía constitucional» de la autonomía local ${ }^{35}$. Una garantía que se proyecta en un contenido dual: por una parte, los arts. 137, 140 y $141 \mathrm{CE}$ garantizan de forma inmediata y directa (a cada municipio, provincia e isla) un «mínimo de autonomía local»; de otra, imponen a todos los poderes públicos (cada

32 Plantea muchas dudas la facultad de disolución de las Corporaciones locales prevista en el art. 61 LRBRL, sobre todo tras la reforma llevada a cabo por la LO 1/2003, de 10 de marzo, para la garantía de la democracia en los Ayuntamientos y la seguridad de los concejales. Sobre esta cuestión véase Octavio SALAZAR BENÍTEZ, «La disolución de las Corporaciones locales como medio de defensa del Estado: un grave atentado contra la autonomía local», Revista de Estudios de la Administración Local. N. ${ }^{2}$ 290, 2002. Págs. 29-59. Este artículo ha recobrado actualidad tras el asesinato por ETA del empresario vasco Ignacio Uría y la negativa de los concejales de ANV de su localidad, Azpeitia (Guipúzcoa), a condenar el crimen. Aunque el partido está ilegalizado, sus concejales y alcaldes se mantienen en 42 ayuntamientos, circunstancia permitida por la legislación vigente. Frente a la iniciativa del PP, que presentó tanto en el Congreso como en el Senado sendas iniciativas para la disolución de estos ayuntamientos, a la que sumó otra similar de la diputada de UPyD Rosa Díez, el Gobierno ha manifestado su intención de «estudiar fórmulas jurídicas para evitar que los concejales de ANV gobiernen en los ayuntamientos» (El País, 6-12-08).

33 Sin ir más lejos, en la primera sentencia que ha dictado sobre un conflicto en defensa de la autonomía local, la STC 240/2006, el Tribunal ha reafirmado la tesis de la «garantía institucional» comparándola con la fórmula recogida en el art. 3 CEAL.

34 Véase Luciano PAREJO, Garantía institucional y autonomías locales. Instituto de Estudios de Administración Local. Madrid, 1981.

35 Joaquín García Morillo, La configuración constitucional de la autonomía local, cit. Pág. 137; Javier GARCÍA RoCA, «Un bloque constitucional local conforme al principio de subsidiariedad...», cit. Pág. 24. 
uno en la esfera de su competencia) la elevación de esos mínimos de esa autonomía local al «máximo de lo posible» ${ }^{36}$.

En este sentido debemos tener presente que la introducción del denominado «conflicto en defensa de la autonomía local» a través de la reforma de la Ley Orgánica del Tribunal Constitucional llevada a cabo por la LO 7/99, de 21 de abril, supuso un avance en el entendimiento «político y constitucional» de la autonomía local. Sin embargo, la deficiente regulación de este conflicto, lastrado sobre todo por la selectiva legitimación activa exigida y por los «obstáculos» que las entidades locales deben sortear en un breve plazo de tiempo, lo han convertido en un instrumento ineficaz y necesitado de una urgente reforma ${ }^{37}$.

Por otra parte, la indefinición del marco competencial de los entes locales ha propiciado que sea la legislación sectorial la que delimite su ámbito de actuación ${ }^{38}$. Esto ha dado lugar a unas entidades locales especialmente «vulnerables», situadas entre un Estado habituado al centralismo y unas CC.AA. en pleno proceso de afirmación institucional ${ }^{39}$. En este contexto, en la mayoría de las ocasiones los Ayuntamientos se han limitado a ejecutar decisiones autonómicas o estatales, quedando reducido al máximo su capacidad de adoptar políticas propias ${ }^{40}$. En algunos casos el legislador, sobre todo el autonómico, ha

36 Francisco Velasco CABALLERo, «Estatutos de autonomía, leyes básicas y leyes autonómicas en el sistema de fuentes del Derecho local», cit. Pág. 126.

37 Véase Javier GARCÍA ROCA, «La primera sentencia constitucional sobre el conflicto en defensa de la autonomía local (STC 240/2006): una ocasión perdida», Cuadernos de Derecho Local. N. ${ }^{\circ}$ 14, 2007. Págs. 14-23.

38 La LRBRL no ofrece una lista determinada de competencias locales, sino que remite esa función a las leyes reguladoras de los diversos sectores de la actividad administrativa (art. 25). Sí establece que una lista de obligaciones municipales mínimas (art. 26) así como un principio de reserva a favor de los entes locales de algunos servicios públicos esenciales (art. 86.3). Como denunciaba el Libro Blanco, la mayoría de las obligaciones del art. 26 hacen referencia al mero establecimiento o prestación de servicios, sin incluir claramente potestades de regulación o de intervención. Además muchos de los servicios incluidos ha ido desapareciendo en los últimos años (por ejemplo, mataderos). La misma crítica cabe realizar al art. 86.3.

El art. 28 reconoce una capacidad general de iniciativa de a favor de los municipios y de su capacidad para prestar servicios complementarios a los propios de otras Administraciones públicas. En relación a las mate-

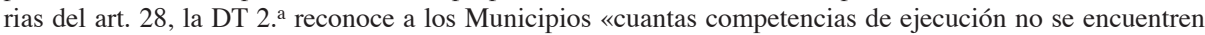
conferidas por dicha legislación sectorial a otras Administraciones públicas». A su vez, el art. 4 lleva a cabo una regulación sumaria de las principales potestades administrativas de que disponen los municipios, pero sin relacionarlas con el régimen de competencias. Finalmente, señalar que el art. 25.3 establece un principio de reserva de ley para regular las competencias locales y que se lleva a cabo una distinción entre las competencias propias y las delegadas (art. 27).

39 El Libro Blanco analizaba con precisión las principales debilidades de este modelo: a) La definición insuficiente de las competencias locales; b) Su falta de adaptación de las competencias locales a las funciones propias de la administración pública liberalizadora; c) La vigencia de una concepción patrimonialista de la autonomía local; d)Anacronismo y falta de adaptación a las nuevas realidades; e) Las limitaciones de la potestad normativa local; f) El control y la coordinación por otras administraciones públicas; g) El incremento de las obligaciones, las responsabilidades o cargas municipales; h) la proliferación de órganos colegiados con representantes municipales de escasa utilidad para la autonomía local, i) El uniformismo del régimen local y de las competencias municipales.

40 Como muy bien ha subrayado Francisco VELASCO, «parecería que los controles autonómicos de legalidad y oportunidad, prohibidos por los artículos 65 y ss de la LBRL (en relación con las «competencias locales 
pretendido «compensar» esas limitaciones mediante la participación de los ayuntamientos en entidades y en procedimientos en los que, al menos formalmente, se consideraban representados los intereses municipales. Una práctica que no ha contribuido a la coordinación en la medida en que no se partía de situaciones paritarias entre las administraciones implicadas.

Finalmente, aunque tal vez habría que situarlo en la cabecera de estas reflexiones, la autonomía política de los entes locales queda vaciada de contenido si no se garantiza su autonomía financiera (art. $142 \mathrm{CE}$ ). En este sentido, el art. 9 CEAL deja claro que las entidades locales tienen derecho a tener «recursos propios suficientes de los cuales pueden disponer libremente en el ejercicio de sus competencias» ${ }^{41}$, los cuales deben ser proporcionales a las competencias previstas por la Constitución y la ley ${ }^{42}$. Sin embargo, a lo largo de estos 30 años, las corporaciones locales han carecido de un espacio competencial y sobre todo financiero que les permitiera llevar a cabo una auténtica «dirección política» ${ }^{43}$. Basta con repasar el reparto del gasto público entre los tres niveles territoriales. En los últimos años las CC.AA. se han situado alrededor del $35 \%$ del gasto público, el Estado en el $49 \%$ y los municipios apenas si han sobrepasado el $15 \%{ }^{44}$. Un porcentaje muy lejano de la media europea (situada en el $24 \%$ para los municipios) y del que le correspondería en un deseable reparto del gasto público entre los tres niveles territoriales: 40\% (Estado), 35\% (CC.AA.),

propias») hubieran reaparecido en una forma más sutil: troceando la competencia local, haciendo su ejercicio «bifásico», «compartido» o «vinculado»». «El Estado de la autonomía local en 2007», cit. Pág. 46.

41 El art. 9 CEAL insiste en que los recursos de las entidades locales deben ser proporcionales a las competencias atribuidas por la Constitución y la ley, y concreta una serie de principios a tener en cuenta en esta materia: una parte al menos de los recursos financieros de las Entidades locales debe provenir de ingresos patrimoniales y de tributos locales respecto de los que tengan la potestad de fijar la cuota o el tipo dentro de los límites de la Ley; los sistemas financieros sobre los cuales descansan los recursos de que disponen las Entidades locales deben ser de una naturaleza suficientemente diversificada y evolutiva como para permitirles seguir, en la medida de lo posible y en la práctica, la evolución real de los costes del ejercicio de sus competencias; la protección de las Entidades locales financieramente más débiles reclama la adopción de procedimientos de compensación financiera o de las medidas equivalentes destinadas a corregir los efectos del desigual reparto de las fuentes potenciales de financiación, así como delas cargas que les incumben, los cuales a su vez no deben reducir la libertad de opción de las Entidades locales, en su propio ámbito de competencia; las Entidades locales deben ser consultadas según formas apropiadas sobre las modalidades de adjudicación a éstas de los recursos redistribuidos; en la medida de lo posible, las subvenciones concedidas a las Entidades locales no deben ser destinadas a la financiación de proyectos específicos y no deberán causar perjuicio a la libertad fundamental de la política de las Entidades locales, en su propio ámbito de competencia; con el fin de financiar sus gastos de inversión, las Entidades locales deben tener acceso, de conformidad con la Ley, al mercado nacional de capitales.

42 Debemos recordar que hasta el año 1988 no se aprueba una ley reguladora de las Haciendas locales, la ley 39/88, de 28 de diciembre, la cual sería reformada por la Ley 51/2002, de 27 de diciembre. En el 2004 se aprobó mediante el Real Decreto Legislativo 2/2004, de 5 de marzo, el texto refundido de dicha ley.

43 A lo que habría que sumar el coste político que para cualquier Ayuntamiento supone acudir a la subida de los impuestos para sufragar las mejoras en los servicios públicos. Albert SolÉ OLLÉ, «Economía política de los gobiernos locales. Una valoración del funcionamiento de los municipios», Actual. N. ${ }^{\circ}$ 15, 2007. Pág. 8.

44 Son los datos procedentes de la Secretaría de Estado de Cooperación Territorial, correspondientes a las estimaciones de 2004. Recogidos en el Libro Blanco para la Reforma del Gobierno Local. 
$25 \%$ (municipios $^{45}$. A todo ello habría que sumar que la mayor parte de sus ingresos son recibidos por los municipios a través de subvenciones condicionadas o que las Comunidades Autónomas aún no han articulado la obligación que les impone el art. $142 \mathrm{CE}$ para que las entidades locales participen en los tributos autonómicos. Sin olvidar que aproximadamente un 30\% del gasto de los Ayuntamientos se destina a las denominadas «competencias impropias», es decir, a cubrir determinados servicios no satisfechos por otras Administraciones. De ahí la urgencia de replantear las bases de un sistema de financiación que prácticamente ha ignorado a los entes locales y que se ha construido en función del proceso descentralizador en las Comunidades Autónomas ${ }^{46}$. Un sistema de financiación que deberá tener en cuenta la fragmentación de nuestro mapa municipal así como el elevado número de pequeños municipios, de manera que el mismo deberá replantearse en conexión no sólo con el reparto competencial sino también con las necesarias estructuras inter y supra municipales.

\section{EL CARÁCTER BIFRONTE DEL RÉGIMEN LOCAL}

La STC 84/1982 acuñó la fórmula «carácter bifronte» para referirse al régimen jurídico de las entidades locales. Con ella se aludía a la responsabilidad compartida por el Estado de dotar de contenido a la autonomía local respetando en todo caso el marco constitucional ${ }^{47}$. Sin embargo, en la práctica los resultados han sido más bien lesivos para la autonomía local. Por una parte, porque esa responsabilidad compartida ha seguido amparado la indefinición competencial, y a su vez la insuficiencia financiera, de los entes locales. Por otra, porque al amparo del 149.1.18. a , el Estado ha mantenido una interpretación extensiva de las «bases del régimen jurídico» de las Administraciones locales, limitando tanto la capacidad normativa autonómica como el margen de actuación de los propios entes locales. De esta manera, y como denunciaba el Libro Blanco, «el municipalismo ha sido un convidado de piedra y el pagano de los conflictos de competencia entre el Estado y las CC.AA.» ${ }^{48}$.

\footnotetext{
45 Véase el estudio de Carmen Luisa GiL-Ruiz GiL-ESPARZA y Jaime IGLeSIas QuinTANA, El gasto público en España en un contexto descentralizado (consultado en la página web www.ief.es/publicaciones/revistas/PGP/47_Gl.pdf, 28-11-2008).
}

46 Muchas de las situaciones irregulares que se han producido en la vida local española en los últimos años han sido debidas en buena parte a los problemas de financiación de los ayuntamientos, los cuales han recurrido a los recursos financieros a corto plazo derivados de la reclasificación del suelo. El caso más extremo fue el del Ayuntamiento de Marbella, el cual provocó que por vez primera el Gobierno utilizara la vía prevista en el art. 61 LRBRL, procediendo a su disolución mediante el Real Decreto 421/2006, de 7 de abril.

47 «El concepto no fue ideado para precisar el papel constitucional de la autonomía local y su «posición» dentro de la organización territorial del Estado. Muy por el contrario, su única razón de ser fue la de servir de presupuesto justificativo del deslinde entre las competencias legislativas del Estado y de las CC.AA., operando como refuerzo de los títulos de intervención del primero». Francisco CAAMAÑO, «Autonomía local y Constitución...», cit. Pág. 167.

48 Debemos recordar que desde un primer momento una buena parte de los Estatutos de Autonomía asumieron como competencia exclusiva el régimen local. Fue el caso del País Vasco (art. 10.4), Cataluña (art. 9.8), 
Asumidas las dificultades que plantea la delimitación del concepto de «normativa básica», así como la inevitable conflictividad que genera en un modelo territorial en el que un largo listado de competencias están repartidas entre diversas instancias territoriales, la Ley 7/1985, de 2 de abril, Reguladora de las Bases de Régimen Local ha cumplido la función constitucional de concretar la garantía constitucional de la autonomía local, convirtiéndose por tanto en «norma de cabecera» del correspondiente grupo normativo ${ }^{49}$. Ahora bien, y como apuntaba el Libro Blanco, el legislador básico debería haberse limitado a «hacer aflorar los componentes de la d autonomía local constitucionalmente protegida (...) desvelar lo que ya está implícitamente delimitado en la Constitución». Sin embargo, ha sobrepasado esos límites, convirtiéndose en una especie de guardián de la autonomía local y optando por un régimen jurídico excesivamente uniforme y exhaustivo y por tanto ineficaz, dada la diversidad del mapa municipal español.

La jurisprudencia del TC ha ido evolucionado, sobre todo a partir de los años noventa, en el sentido de otorgarle un mayor protagonismo a las CC.AA. (véanse por ejemplo, las SSTC 331/1993, 109/98), si bien ello no ha supuesto «una exclusiva interiorización» del sistema local en dicho ámbito territorial ${ }^{50}$. Este proceso ha avanzado significativamente, como veremos más adelante, en las reformas estatutarias llevadas a cabo en la VIII Legislatura, las cuales han supuesto, con algunos matices, un paso significativo en lo que se ha venido llamando «segunda descentralización», la cual reclama que las Comunidades Autónomas ostenten «capacidad suficiente para incidir efectivamente en la configuración del régimen de los entes locales de su territorio en los que se requiere que vaya a descansar el grueso de determinadas actuaciones públicas» ${ }^{51}$.

Galicia (art. 27.2), Andalucía (art. 13.3), La Rioja (art. 8), Murcia (art. 11.9), Aragón (art. 35.2). En la mayor parte de estos textos se especificaba que dicha competencia se asumía «sin perjuicio de lo que dispone el número $18 \mathrm{del}$ apartado $1 \mathrm{del}$ art. 149 de la Constitución». Otro grupo de Estatutos asumieron la competencia de desarrollo legislativo y de ejecución del régimen local en el marco de la legislación básica del Estado: Asturias (art. 11), Castilla-La Mancha (art. 32.1), Canarias (art. 32.4), Extremadura (art. 8.1), Islas Baleares (art. 11.2), Madrid (art. 27), Castilla-León (art. 34.3). Este último es el único que contenía un capítulo específico dedicado a la organización territorial. El art. 24.2 del Estatuto de Cantabria incluye entre las materias de competencia exclusiva de la CA «las alteraciones de los términos municipales comprendidos en tu territorio y, en general, las funciones que corresponden a la Administración del Estado sobre las Corporaciones Locales, y cuya transferencia autorice la legislación sobre régimen local». La LO 13/82, de 10 de agosto, por la que se aprueba el Estatuto de Reintegración y Amejoramiento del Régimen foral de Navarra dispone en su art. 46 que en materia de Administración local le corresponde a Navarra las facultades y competencias que ostenta de acuerdo con la ley paccionada de 1841, el Real Decreto-ley paccionado de 4 de noviembre de 1925 y disposiciones complementarias. Además, le corresponde aquellas que, siendo compatibles con las anteriores, puedan corresponder a las CC.AA. o a las Provincias conforme a la legislación básica del Estado.

49 Luciano PAREJo ALFONSO, «La ley 30/92 y la Ley 7/85: una valoración global de la integración del régimen básico de la Administración Local en el conjunto de las Administraciones Públicas», Anuario de Gobierno Local, 2005. Pág. 43.

50 Tomás FONT i LLOVET, «La autonomía local en España a los veinte años de la Constitución: perspectivas de cambio», Anuario de Gobierno local 1998, pág. 39.

51 Tomás FONT I LLOVET, «Reforma básica y desarrollo del gobierno local: entre Estado y Comunidades Autónomas», Anuario de Gobierno Local 2002. Pág. 21. 
En todo caso, este proceso conlleva el riesgo de que se sustituya el poder configurador del Estado por el de las CC.AA., manteniendo restringida de manera similar la autonomía local ${ }^{52}$. Algo que es especialmente evidente en la limitada capacidad de autoorganización de los municipios españoles ${ }^{53}$.

Debemos recordar que el originario art. 5 LRBRL disponía que, en materia organizativa y de funcionamiento de sus órganos, las entidades locales se regirían por la Ley de Bases, por las leyes autonómicas sobre régimen local y por el Reglamento orgánico propio de cada entidad (ROM) en los términos previstos en dicha ley. El legislador estatal concedió en un principio primacía al ROM sobre la legislación autonómica, la cual sólo se aplicaría en el caso de que la entidad local no hubiese aprobado su ROM o bien guardara silencio en él sobre algún aspecto organizativo. Este sistema sufrió una mutación como consecuencia de la STC 214/1989, de 21 de diciembre, en la que el TC entendió que dicha regula-

52 Llama la atención sobre este peligro Gerardo RUIZ-RICO cuando señala que «la recepción estatutaria del principio de autonomía tiene que intentar romper en lo posible la dinámica «competitiva» entre entes locales y comunidad autónoma, a la que pertenecen territorialmente y de la que dejan de formar parte también institucionalmente, sea por su potencial unifrontalidad o todavía debido a su carácter bifronte. De poco serviría - en orden a garantizar mejor las funciones constitucionales de los gobiernos locales - sustituir la hasta hoy tutela del legislador básico estatal por otra especie de protectorado autonómico sobre los entes locales». «Niveles de organización territorial y reformas en los Estatutos de autonomía», Anuario de Gobierno Local, 2004. Pág. 174.

53 El esquema organizativo previsto por la LRBRL, a la que habría que sumar las previsiones en materia de elecciones municipales realizadas por la LOREG, es excesivamente uniforme. El legislador ha previsto tres fórmulas de gobierno municipal, de acuerdo con criterios básicamente demográficos: $\left.1 .^{\circ}\right)$ Los municipos que se rigen por el sistema de concejo abierto (los de menos de 100 habitantes y los que tradicionalmente se hubiesen regido por dicho sistema, así como otros en los que sea aconsejable adoptarlo), en los cuales se elige al Alcalde directamente por medio de un sistema mayoritario, mientras que los asuntos más importantes se deciden en una asamblea formada por todos los vecinos; $2^{\circ}$ ) Los municipios que tengan menos de 250 habitantes y que no se rijan por concejo abierto, que eligen 5 concejales por un sistema mayoritario y de listas abiertas; $3 .^{\circ}$ ) El modelo «ordinario», que es el vigente en la mayoría de los municipios españoles, basado en la elección de los concejales por un sistema proporcional y en la elección indirecta del Alcalde. Este modelo responde a las características de un sistema parlamentario, si bien con un marcado carácter presidencialista en la configuración del Alcalde. Como consecuencia del acuerdo adoptado entre la FEMP y el Gobierno, contenidas en las Medidas para el desarrollo del Gobierno Local que concretaron el llamado Pacto local a finales de los noventa, fueron reformadas tanto la LRBRL (Ley 11/99, de 21 de abril) como la LOREG (LO 8/99, de 21 de abril) con el objetivo de fortalecer el gobierno local y la estabilidad de las corporaciones locales. Para ello se atribuyeron a los alcaldes funciones de carácter ejecutivo que antes estaban atribuidas al Pleno, del que se reforzaron sus funciones de control político. Además se perfeccionó la institución de la moción de censura y se introdujo una nueva institución de control a iniciativa del Alcalde, la cuestión de confianza.

A este sistema habría que sumar el régimen específico de las ciudades de Madrid y Barcelona previsto en la DA 6. ${ }^{a}$ LRBRL. En el caso de Barcelona, fue desarrollado por la Ley catalana 22/98, de 30 de diciembre, de la Carta Municipal de Barcelona y por la Ley 1/2006, de 13 de marzo, por la que regula el régimen especial del municipio de Barcelona. En Madrid hubo que esperar hasta el 2006 cuando se aprobó la ley 22/06, de 4 de julio, de capitalidad y régimen especial de dicha ciudad. A partir de la reforma llevada a cabo por la Ley 57/2003 se configuró un régimen específico para los «municipios de gran población». Cabe destacar también como en los últimos años han proliferado las disposiciones relativas a las capitalidades de las CC.AA.. Es el caso por ejemplo de la Ley 4/02, de 25 de junio, del estatuto de la capitalidad de Santiago de Compostela o de las más recientes Ley 8/08, de 15 de junio, de modificación de la Ley 23/06, de 20 de diciembre, de la capitalidad de Palma de Mallorca, o de la Ley 8/07, de 13 de abril, de la capitalidad compartida de las ciudades de las Palmas de Gran Canaria y Santa Cruz de Tenerife. 
ción contradecía el orden constitucional de distribución de competencias entre el Estado y las CC.AA. La sentencia, que sería unánimemente criticada por la doctrina, afirmó que las normas autonómicas no podían tener un valor supletorio o subsidiario con respecto a los reglamentos orgánicos municipales. En un voto particular, el magistrado Díaz Eimil mantuvo una posición más ajustada a la protección de la autonomía local, según la cual en lo referente a la organización complementaria debería ser prioritaria la capacidad de autoorganización de los municipios. Mantener lo contrario supondría reconocer «una especie de competencia básica de segundo grado» a las Comunidades Autónomas. Junto a estos argumentos, cabría recordar que el TC pasó por alto, como fue habitual durante dos décadas, los principios contenidos en la CEAL. Entre ellos el establecido en el art. 6.1 según el cual «sin perjuicio de las disposiciones generales creadas por la ley, las entidades locales deben poder definir por sí mismas las estructuras administrativas internas con las que pretenden dotarse, con objeto de adaptarlas a sus necesidades específicas y a fin de permitir una gestión eficaz» ${ }^{54}$.

Tanto la reforma de la LRBRL llevada a cabo en 1999 como la más reciente del 2003 favorecieron la configuración de un régimen local extremadamente uniforme y rígido en el que apenas si caben diferenciaciones organizativas en función de los caracteres y necesidades de cada municipio. Ello incide en lo que podríamos considera el «núcleo duro» de la autonomía local. Si la autonomía hace referencia a la «gestión de sus propios intereses» (art. $137 \mathrm{CE}$ ) es indudable que un elemento fundamental para llevar a cabo esa gestión es la dotación por el propio municipio de una organización que se adapte a sus características, de manera que deberían ser los Reglamentos orgánicos los que prioritariamente establecieran la organización del municipio. La legislación básica estatal debería limitarse a establecer unos principios muy generales y la autonómica debería tener siempre carácter supletorio.

La reforma de la LRBRL llevada a cabo por la Ley 57/2003, denominada de manera excesivamente generosa «de medidas para la modernización del gobierno local», subrayó una vez más los dos defectos más acusados del régimen local: la uniformidad y la densidad de las normas básicas estatales. Y ello a pesar de que la misma exposición de motivos de la ley apuntaba que uno de sus objetivos principales era romper la homogeneidad del modelo orgánico-funcional de nuestros municipios ${ }^{55}$. El legislador volvió a limitar la capacidad de autoorganización de unos municipios que por sus características singulares deberían disponer

\footnotetext{
54 La legislación autonómica de régimen local aprobada en las últimas décadas ha aportado escasas novedades con respecto al esquema organizativo previsto por la LRBRL, aunque bien es cierto que el margen del que disponían era muy estrecho. La mayoría de las leyes autonómicas se han limitado a reiterar los órganos necesarios establecidos por la LRBRL y las que contemplan con más detalle una organización complementaria se ajustan en gran medida a las previsiones del ROF. Un análisis detallado de estas leyes puede verse en Octavio SAlaZAR BeníteZ, El sistema de gobierno municipal. C.E.P.C. Madrid, 2007. Págs. 94-97.

55 Tal vez no haya habido en los últimos años una ley que haya suscitado tan elevado grado de unanimidad en cuanto a su valoración negativa. Un resumen de las opiniones de la doctrina puede verse en Octavio SALAZAR, El sistema de gobierno municipal, cit. Pág. 98.
} 
de una mayor libertad en la definición de sus estructuras de gobierno. Para estos «municipios de gran población» habría sido más conveniente un régimen de carta y no la extensión de un modelo de gobierno y administración que sólo tiene sentido en las ciudades que verdaderamente son «grandes» ${ }^{56}$. Por otra parte, quedaron sin atender los problemas organizativos y financieros de los pequeños municipios que son la mayoría en nuestro país (aproximadamente un 85,7\% de los 8.108 municipios españoles tienen menos de 5000 habitantes).

\section{LA INTERIORIZACIÓN DEL RÉGIMEN LOCAL EN LOS ESTATUTOS DE AUTONOMÍA}

La Recomendación del Consejo de Europa 121 (2002) sobre la democracia local y regional en España llamó la atención sobre la necesidad de reforzar el papel de las Comunidades Autónomas como garantes de los regímenes jurídicos y financieros de las colectividades locales. Dada la diversidad del mapa municipal español, y de las singularidades que las entidades locales poseen en cada Comunidad, se estimaba conveniente que fuera ésta la que tuviese un papel esencial en su ordenación territorial interna ${ }^{57}$. Ese papel debería plasmarse en su «norma institucional básica» puesto que «un verdadero proceso descentralizador en el interior de las distintas Comunidades Autónomas no podrá llevarse a cabo por simple voluntarismo político ni por la eventual presión, siempre relativa y mediatizada, de las correspondientes federaciones de municipios y demás entidades locales. Lo realmente decisivo y condicionante va a ser la existencia, o no, de un modelo legalmente obligatorio y vinculante que para ser efectivo, debe tener... rango estatutario» 58 .

\footnotetext{
56 El aspecto más discutible de dicha ley es el heterogéneo ámbito de aplicación del Título X LRBRL. El art. 121 LRBRL optó por combinar el criterio demográfico - los municipios cuya población supere los 250.000 habitantes o las capitales de provincia cuya población los 175.000 habitantes - con otros como ser capital de provincia, capital autonómica, sede de instituciones autonómicas o, de manera muy genérica, presentar circunstancias económicas, sociales, históricas o culturales especiales. En estos supuestos se exige la decisión favorable de las Asambleas Legislativas correspondientes a iniciativa de los respectivos Ayuntamientos. Esto ha provocado que en los últimos años se haya extendido este régimen a ciudades que no se caracterizan precisamente por tener una «gran población». Es el caso por ejemplo de Cuenca, con sólo 47.862 habitantes, o Mérida, con 52.200 habitantes.
}

57 Hay que tener en cuenta que «la distribución territorial de la potestad legislativa que resulta hoy (y, en el futuro, si acaso en mayor medida) del bloque de constitucionalidad sitúa en la disposición de las comunidades autónomas la práctica totalidad de las materias en las que se hacen o pueden hacerse presentes normalmente los intereses de las colectividades locales». Luciano PAREJO ALFONSO, «Una visión sobre el gobierno local», cit. Pág. 69. En este sentido hay que interpretar la afirmación de Tomás FonT i LLOVET según la cual el municipio «se relaciona preferentemente con mayor naturalidad con las instituciones autonómicas», lo cual no quiere decir que pertenezca a la Comunidad Autónoma. En este sentido es en el que debemos entender el polémico art. 2.3 del Estatuto catalán cuando afirma que «los municipios, las veguerías, las comarcas y los demás entes locales que las leyes determinen, también integran el sistema institucional de la Generalitat, como entes en los que ésta se organiza territorialmente, sin perjuicio de su autonomía». El régimen local en la reforma de los Estatutos de Autonomía. C.E.P.C. Madrid, 2006. Pág. 19.

58 Tomás FonT i LLOVET, «Estado autonómico y gobierno local: el inicio de un nuevo ciclo», Anuario de Gobierno Local 2005. Págs. 14-15. Hay que tener en cuenta que en las dos últimas décadas una buena parte 
La urgencia de esta tarea se puso de manifiesto en el posicionamiento que mantuvo el TC en la sentencia 240/2006, de 20 de julio, la primera dictada en un conflicto en defensa de la autonomía local. En ella el TC relativizó el papel de la LRBRL como garante de la autonomía local frente al legislador, al estimar que la misma no se integra en el bloque de la constitucionalidad y que sólo podría actuar como canon de validez de la ley autonómica «en aquellos aspectos enraizables directamente en los artículos 137, 140 y 141 de la CE». Esta resolución puso de manifiesto la necesidad de concretar los parámetros que sirvan para proteger la autonomía local frente al legislador. Una tarea que en buena medida puede corresponder al Estatuto de Autonomía, los cuales, como algún autor ha señalado, pueden convertirse en la norma institucional básica de los entes locales. ${ }^{59}$

Este objetivo ha empezado a encontrar plasmación en las recientes reformas estatutarias, las cuales han supuesto un avance hacia la denominada «segunda descentralización» así como en la configuración de un modelo más próximo al característico de los sistemas federales en los que la competencia sobre régimen local corresponde a cada uno de los Estados miembros ${ }^{60}$. Jurídicamente, y tal

de Comunidades Autónomas han aprobado sus normas específicas de régimen local (Ley 7/99, de 9 de abril, de Administración Local de Aragón; Ley 20/2006, de15 de diciembre, Municipal y de Régimen local de las Illes Balears; Ley 14/90, de 26 de julio, de reforma de la Ley 8/86, de 18 de noviembre, de régimen jurídico de las Administraciones Públicas de Canarias; Ley 3/91, de 14 de marzo, de régimen de las Entidades locales de Castilla-La Mancha; Ley 1/98, de 4 de junio, de Régimen Local de Castilla-León; Decreto Legislativo 2/2003, de 28 de abril, por el que se aprueba el texto refundido de la Ley Municipal y de Régimen local de Cataluña; Ley 5/1997, de 22 de julio, de Administración local de Galicia; Ley 1/2003, de 3 de marzo, de la Autonomía Local de La Rioja; Ley 2/2003, de 11 de marzo, de la Administración local de la Comunidad de Madrid; Ley 6/88, de 25 de agosto de Régimen Local de la región de Murcia; ley foral 6/90, de 2 de julio, de Administración local de Navarra, actualizada por la ley foral 11/2004, de 29 de octubre). Junto a estas disposiciones, se situarían otras que han incidido en la organización territorial, en entidades locales singulares o en aspectos concretos del régimen jurídico local. Sería el caso por ejemplo de la Ley 3/1983, de 1 de junio, de organización territorial de la Comunidad Autónoma de Andalucía o la ley 7/93, de 27 de julio, de demarcación municipal de dicha Comunidad; la ley 3/86, de 15 de mayo, por la que se regula la creación de comarcas del Principado de Asturias, o en la misma Comunidad la ley 10/86 de demarcación territorial de los Concejos y la 11/86, de reconocimiento de la personalidad jurídica de la parroquia rural. En Baleares nos encontramos con la Ley 8/2000, de 27 de octubre, de Consejos Insulares. En Cantabria, las leyes 6/94, de 19 de mayo, de entidades locales menores y la 8/99, de 28 de abril, de Comarcas. En Murcia, la Ley 7/83, de 7 de octubre, de descentralización territorial y colaboración de la CA con las entidades locales. En Madrid, la ley 13/2003, de 11 marzo, para el desarrollo del pacto local en dicha Comunidad. Destacar también como en Valencia se aprueba la Ley 2/01, de 11 de mayo, de creación y gestión de las áreas metropolitanas.

59 Juan Luis REQUEJo PAGÉs, «Garantía de la autonomía local y estatutos de autonomía», Anuario de Gobierno Local, 2006. Pág. 56. No faltan posiciones en contra de este argumento. Por ejemplo, José Luis RiVERO YSERN que considera que el Estatuto no es el cauce para fijar las Bases del Régimen Jurídico de la Administración Local. «El régimen local en el nuevo Estatuto de Autonomía de Andalucía. Reglas sustantivas y distribución de competencias», Santiago MuÑOz MACHADO y Manuel RebOllo PUIG, Comentarios al Estatuto de Autonomía de Andalucía. Civitas. Pamplona, 2008. Pág. 842.

60 De acuerdo con este sistema, «la autonomía local no es idéntica en toda España. Lo será en sus «niveles mínimos» (los fijados directamente por la Constitución); en los niveles más elevados fijados en la Carta Europea de Autonomía Local, de 1985; y en los «niveles básicos», fijados por el Estado al amparo de su competencia ex artículo 149.1.18 CE. Más allá, serán los estatutos y las leyes autonómicas quienes dando cumplimiento al «principio constitucional» de autonomía local, determinen el nivel final de autonomía de los municipios y las provincias en cada comunidad autónoma». Francisco VELASCO CABALLERO, «Estatutos de autonomía, leyes básicas y leyes autonómicas en el sistema de fuentes del Derecho local», cit. Pág. 128. 
como ha dejado claro el TC (sentencia 247/2007), no hay ninguna dificultad en que los Estatutos incorporen unas mayores garantías de la autonomía local, siempre, claro está, que respeten los mínimos constitucionales ${ }^{61}$.

Por lo tanto, cabría avanzar en nuevo modelo de régimen local en el que junto a una clarificación competencial entre las distintas entidades territoriales se produzca una reducción de lo básico, limitado a concretar el contenido mínimo de la autonomía local, y un mayor protagonismo de los Estatutos de autonomía. Este proceso plantea una primera dificultad consiste en redefinir la posición de los Estatutos en relación a la legislación básica estatal. Estoy de acuerdo con la doctrina que, ajustándose a varios enjuiciamientos del TC (sentencias 214/1989; 27/1987, 109/1988), estima que dicha legislación ocupa una posición infraordenada respecto a las normas institucionales básicas de las Comunidades Autónomas. De manera que una norma básica estatal será inaplicable cuando entre en conflicto con un Estatuto ${ }^{62}$. Ahora bien, en aplicación del principio constitucional de autonomía local, «la aplicación del Estatuto puede considerarse condicionada a que su regulación no reduzca los "estándares básicos" de la autonomía local fijados por el Estado» ${ }^{63}$.

El problema es que estos procesos no se han llevado a cabo de manera coordinada con la anunciada reforma de la legislación básica de régimen local. De esta forma se ha vuelto a incidir en uno de los principales «males» de nuestro proceso de descentralización: la ausencia de una coordinación multilateral, con los consiguientes problemas de articulación jurídica, y el predominio de un bilateralismo condicionado por las circunstancias políticas centro-periferia. Las reformas estatutarias se han realizado de forma paralela al debate en torno al gobierno local, sin que en ningún momento haya habido coordinación entre ambos procesos. Habría sido más correcto jurídicamente haber planteado la

61 Como ha sostenido la doctrina, no hay inconveniente en que los Estatutos incorporen contenidos que superen los mínimos que les marca el art. 147.2 CE. Véase en este sentido César AGUADo RENEDO, El Estatuto de autonomía y su posición en el ordenamiento jurídico. C.E.C. Madrid, 1996. Págs. 361-364.

62 Es la posición que reiteradamente ha mantenido por ejemplo Francisco VELASCO, «Estatutos de autonomía, leyes básicas y leyes autonómicas en el sistema de fuentes del derecho local», cit. Pág. 135. También en «El estado de la autonomía local en 2007», cit. Pág. 31. En contra de esta posición cabe destacar la argumentación de Luis ORTEGA, el cual considera que «los entes locales, además de que son declarados desde la Constitución «Estado» a los mismos efectos de caracterizarlos como poder público, no por eso se integran en los espacios ordinamentales autonómico y estatal, sino que su propio espacio debe estar garantizado de una forma autónoma». «Régimen local y Estatutos de Autonomía», Revista General de Derecho Administrativo. N. ${ }^{\circ}$ 12, junio 2006. Pág. 5. Véase también sus aportaciones en El régimen local en la reforma de los Estatutos de autonomía, cit., o en Legislación básica y Estatutos de autonomía. C.E.P.C. Madrid, 2006.

63 Francisco VelasCO, «El estado de la autonomía local en 2007», cit. Pág. 32. En un sentido similar se pronuncia Tomás FONT I LLOVET cuando afirma que «ante un eventual supuesto de menor garantía por parte de un estatuto en relación con la Ley básica, su interpretación conforme al principio constitucional de autonomía local permitiría la aplicación preferente de la norma más protectora. «Autonomía local y estatutos: crónica de un compromiso», Anuario de Gobierno Local, 2006. Pág. 27. En contra de que los Estatutos limiten las bases del Estado véase por ejemplo Janini DE LA QUADRA SALCEDO, «Es el Estatuto de autonomía una norma capaz de modular el alcance de la legislación básica del Estado?», Revista Española de Derecho Constitucional. N. ${ }^{\circ}$ 72, 2004. Págs. 135-161. 
reforma del gobierno local con la debida coordinación entre el ámbito propio del Estado - la legislación básica - y el de las Comunidades Autónomas. Todo ello por no hablar de la necesaria reforma constitucional que debería haber precedido a todas las reformas estatutarias. Pero, como ha sido lo habitual a lo largo del proceso autonómico, una vez más la oportunidad política le ha ganado la partida a la racionalidad jurídica ${ }^{64}$.

Los Estatutos de autonomía aprobados en 2007 (LO 1/2007, de 28 de febrero, de reforma del Estatuto de Autonomía de las Illes Balears, EAB; LO 2/2007, de 19 de marzo, de reforma del Estatuto de Autonomía para Andalucía -EAA -; LO 5/2007, de 20 de abril, de reforma del Estatuto de autonomía de Aragón -EAR - ; y LO 14/2007, de 30 de noviembre de reforma del Estatuto de Autonomía de Castilla y León; ECL) siguieron muy cerca las previsiones que en esta materia realizaron la LO 6/2006, de 19 de julio, del Estatuto de Autonomía de Cataluña (EAC), y en menor medida la LO 1/06, de reforma del Estatuto de la Comunidad Valenciana (EAV). A continuación analizo las principales aportaciones que realizan estas normas en materia de régimen local.

\section{Asunción de la competencia sobre régimen local}

En los nuevos Estatutos encontramos diversas opciones a la hora de delimitar la competencia sobre régimen local, lo cual pone de manifiesto la confusión existente aún en esta materia. El EAV es el que sigue la fórmula más obvia, al incluir el régimen local entre las competencias exclusivas de la Generalitat «sin perjuicio de lo que dispone el número 18 del apartado 1 del art. 149 de la Constitución Española»(art. 49.1.8. ${ }^{a}$ ). A renglón seguido se incluyen las alteraciones de municipios y los topónimos. Esta misma competencia es incluida entre las exclusivas de Baleares (art. 30.2 EAB), si bien el régimen local se incluye entre las de desarrollo legislativo y ejecución (art.31.13 EAB; en los mismos término, el art. 71 ECL). No obstante, el EAB precisa que el régimen local es competencia propia de los Consejos Insulares (art. 70.2).

Es mucho más preciso el EAR, el cual concreta que en materia de régimen local corresponde con carácter exclusivo a la Comunidad Autónoma «la determinación de las competencias de los municipios y demás entes locales en las materias de competencia de la Comunidad Autónoma de Aragón; el régimen de los bienes locales y las modalidades de prestación de los servicios públicos locales, así como las relaciones para la cooperación y colaboración entre los entes locales y entre éstos y la Administración de la Comunidad Autónoma de Aragón. Asimis-

\footnotetext{
64 «... el verdadero desarrollo del Pacto Local consiste hoy en incorporarlo a un verdadero nuevo «Pacto por las autonomías territoriales» que implica el gran acuerdo necesario para la reforma de los Estatutos y para llevar a cabo la determinación básica y diferenciada del papel del gobierno local en el Estado autonómico». Tomás FONT I LLOVET, «La reconstrucción jurídica de la autonomía local: el gobierno local y la reforma de los estatutos», Anuario de Gobierno Local, 2003. Pág. 43.
} 
mo, incluye la determinación de los órganos de gobierno de los entes locales, creados por la Comunidad autónoma y su régimen electoral» (art. 71.5. . $^{\text {) }}$.

Presentan una redacción prácticamente idéntica los Estatutos catalán y andaluz (arts. 160 EAC y 60 EAA). En ambos se incluye dentro del régimen local una serie de materias sobre las que la Comunidad autónoma tiene competencia exclusiva, «respetando el principio de autonomía local», y el art. 149.1.18. ${ }^{a}$ añade el EAA ${ }^{65}$. En todo lo demás, se entiende que a la Comunidad Autónoma le corresponde la competencia compartida. El art. 60.3 EAA añade que «en el marco de la regulación general del Estado, le corresponden a la Comunidad Autónoma de Andalucía las competencias sobre haciendas locales y tutela financiera de los entes locales, sin perjuicio de la autonomía de éstos y dentro de las bases que dicte el Estado de acuerdo con el art. 149.1.18. ${ }^{\mathrm{a}}{ }$.

\section{Organización territorial y competencias de los gobiernos locales}

Es muy significativo que el EAC titule el capítulo VI de su Título II, dedicado a las instituciones, como «El gobierno local» cuando la propia Constitución habla de Administración y no de gobierno local. El largo capítulo VI del Título II EAC empieza afirmando que la organización territorial básica de Cataluña está constituida por municipios y veguerías (art. 83.1), mientras que el ámbito supramunicipal lo está por comarcas que deben ser reguladas por una ley del Parlamento (art. 83.2).

El EAC refuerza la autonomía local desde el momento en que fija un largo listado de competencias propias de las entidades locales de Cataluña (art. 84.2), las cuales se deja muy claro que deben ser ejercidas por dichas entidades «con plena autonomía, sujeta sólo a controles de constitucionalidad y de legalidad» $(\text { art. 84.1 })^{66}$. De manera similar se pronuncia el art. 92 del EAA,,${ }^{67}$ el cual se

\footnotetext{
65 Dichas materias son las relaciones entre las instituciones de la Junta de Andalucía y los entes locales, asî́ como las técnicas de organización y de relación para la cooperación entre los entes locales y entre éstos y la Administración de la Comunidad Autónoma, incluyendo las distintas formas asociativas mancomunales, convencionales y consorciales; la determinación de las competencias y de las potestades propias de los municipios y de los demás entes locales; el régimen de los bienes de dominio público, comunales y patrimoniales y las modalidades de prestación de servicios públicos; la determinación de los órganos de gobierno de los entes locales creados por la Comunidad Autónoma, el funcionamiento y régimen de adopción de acuerdos de todos estos órganos y las relaciones entre ellos; el régimen de los órganos complementarios y la regulación del régimen electoral de los entes locales creados por la Comunidad.
}

66 «La función principal del listado de materias es impedir que la ley sectorial asigne esas tareas o competencias a otras entidades públicas». Francisco VELASCO, «Autonomía local y subsidiariedad...», cit. Pág. 136. En este sentido, el «blindaje de competencias» ayuda a la interpretación de la Constitución. Joaquim FERRET I JACAS, «Nuevas reglas de distribución de competencias sobre régimen local», Anuario de Gobierno Local, 2006. Pág. 43.

67 El problema sigue siendo la exacta delimitación de un núcleo competencial propio ya que la mayor parte de las materias que se enumeran son de competencia compartida. Además, el art. 92 EAA no olvida precisar que las competencias propias lo serán «en los términos que determinen las leyes». Gerardo RUIZ-RICO ha 
incluye en el Título III dedicado a la «Organización territorial de la Comunidad Autónoma» que según el art. 89 se articula sobre los municipios, las provincias y las demás entidades territoriales que puedan crearse por ley. Como aspecto más positivo de esta regulación habría que señalar que dentro de las materias enumeradas aparecen los primeros esbozos de concreción de las funciones que dentro de cada ámbito territorial van a asumir los Ayuntamientos. Además, constituye un gran compromiso político pues contiene una apuesta importante en relación con los llamados servicios básicos ${ }^{68}$.

El Estatuto andaluz regula además con detalle la transferencia y delegación de competencias en los Ayuntamientos, las cuales se someten a importantes limitaciones (art. 93): ha de regularse por ley aprobada por mayoría absoluta; ha de garantizarse la suficiencia financiera para poder desarrollarlas; ha de ajustarse a los principios de legalidad, responsabilidad, transparencia, coordinación y lealtad institucional, quedando en el ámbito de la Junta de Andalucía la planificación y control de las mismas. A continuación, el art. 93.2 EAA introduce unas previsiones que pueden resultar contradictorias. Por una parte, se señala que las competencias que se deleguen o transfieran han de estar referidas sustancialmente a la prestación o ejercicio de las mismas, posibilitando que los municipios «puedan seguir políticas propias». En todo caso, se advierte a continuación, «la Comunidad seguirá manteniendo, cuando se considere conveniente, las facultades de ordenación, planificación y coordinación generales». Es decir, por una parte parece potenciarse el carácter político de la autonomía local, pero ésta queda muy limitada desde el momento en que se insiste en que lo que se deben transferir son fundamentalmente la prestación o ejecución de competencias, conservando la Comunidad las facultades de ordenación y planificación. Mucho me temo que con este planteamiento el margen de actuación municipal sea muy estrecho y se incida en el riesgo ya señalado de sustituir la tutela del Estado por la de la Comunidad autónoma.

A diferencia de los dos anteriores, el EAV no incluye un listado de competencias de los entes locales, remitiendo a una ley de las Cortes que será la que

realizado un completo análisis del listado contenido en dicho artículo, poniendo en evidencia las escasas competencias que podemos calificar de «específicamente municipales» (abastecimiento de aguas, aguas residuales, alumbrado público, limpieza viaria, etc.) La mayoría con competencias compartidas con otras Administraciones (promoción del turismo, de la cultura, del deporte, planificación de viviendas, ordenación urbanística, etc.), mientras que un tercer grupo sería de materias que difícilmente pueden gestionarse con criterios de exclusividad (protección del patrimonio histórico, del medio ambiente, de la salud pública). «Las entidades locales en la proposición de reforma del Estatuto de autonomía de Andalucía», Anuario de Gobierno Local, 2006. Pág. 70. Como bien explica Francisco VELASCO, «En los nuevos estatutos de autonomía ha cambiado de forma trascendente el sistema de distribución de competencias. Ahora sólo una parte de las competencias (pocas) son propiamente «exclusivas» de la Comunidad Autónoma; y en la mayoría de las materias de régimen local las comunidades autónomas disponen de competencia «de desarrollo». El cambio en el sistema no debe entenderse como una pérdida de poder autonómico en materia local, sino como una corrección sobre las desviaciones en el sistema precedente. Ahora, las escasas competencias autonómicas «exclusivas» son propiamente esto, «exclusivas». En ellas, por tanto, no hay espacio para la regulación básica estatal; o más precisamente, una eventual regulación básica estatal no sería de aplicación en la Comunidad autónoma correspondiente». «El estado de la autonomía local en 2007», cit. Pág. 40.

68 José Luis Rivero YSERn, «El régimen local en el nuevo Estatuto de autonomía...», cit. Pág. 851. 
«procederá a la descentralización a favor de los Ayuntamientos de aquellas competencias que sean susceptibles de ello, atendiendo a la capacidad de gestión de los mismos» (art. 64). Una previsión que enlaza con el mandato genérico que encabeza dicho artículo y según el cual «Les Corts impulsarán la autonomía local, pudiendo delegar la ejecución de las funciones y competencias en aquellos Ayuntamientos y entes locales supramunicipales que, por sus medios, puedan asumirlas, asegurando la debida coordinación y eficacia en la prestación de los servicios».

Dada la singularidad del archipiélago, el EAB distingue en su organización territorial entre los Consejos Insulares (capítulo IV, título IV), de los que detalla tanto las competencias propias (art. 70) como las ejecutivas (art. 71) $)^{69}$, y los municipios (capítulo V, título IV). De estos no incluye un listado de competencias, sino que se limita a establecer una cláusula general («Los municipios tienen en el ámbito de este Estatuto y de las leyes, libertad plena para el ejercicio de su iniciativa en cualquier materia que no esté excluida de su competencia o atribuida en exclusiva a otra administración o autoridad», art. 75.4) y a contemplar la posibilidad de delegación por el Estado, por la CA, por los Consejos Insulares o por cualquier otra Administración (art. 75.5) así como la de que asuman en su ámbito territorial la ejecución y gestión de las competencias propias de los Consejos Insulares o de aquellas que les hayan sido previamente transferidas (art. 75.6).

Mucho más tímidas son las previsiones del Estatuto aragonés, cuyo Título VI, dedicado a la «Organización territorial y gobierno local», se encabeza con un artículo que reconoce a los municipios, comarcas y provincias como elementos de la estructura territorial local de Aragón. Sólo encontramos previsiones muy genéricas con respecto a las competencias de estos entes: el art. 82 señala que el Estatuto «garantiza a los municipios la autonomía para el ejercicio de sus competencias propias y la defensa de los intereses de la colectividad que representan»; se mantienen como funciones de las provincias las de «cooperación, asistencia y prestación de servicios a municipios y comarcas» (art. 84) y se remite a una ley la determinación de las competencias de las comarcas (art. 83) así como la aprobación de «la distribución de responsabilidades administrativas entre los diversos niveles de organización territorial, de acuerdo con la legislación básica estatal, respetando la autonomía constitucionalmente garantizada y previendo los medios de financiación suficientes para que pueda llevarse a cabo su ejercicio» (art. 85).

De manera igualmente genérica se pronuncia el Estatuto de Castilla y León al delimitar las competencias de sus entes territoriales, a saber los municipios, provincias y demás entidades locales que puedan crearse conforme a la ley (art.

\footnotetext{
69 «Esta atribución competencial directa difiere de la técnica seguida en los demás estatutos renovados, que reproducen aún la técnica de atribución competencial propia del art. 25.2 LBRL, esto es, la identificación de materias donde las leyes sectoriales deben atribuir competencias a las entidades locales». Francisco VELASCO, «El estado de la autonomía local en 2007», cit. Págs. 29-30.
} 
43). Con respecto a las competencias propias del municipio, el art. 45 remite a la legislación básica del Estado y a la de la Comunidad Autónoma, al tiempo que reconoce que los municipios tienen capacidad para ejercer su iniciativa en toda materia de interés local que no esté expresamente incluida en su competencia o atribuida a otras administraciones por la legislación del Estado o la Comunidad Autónoma. En el caso de las comarcas, se hace una remisión a la ley que será la que fijará sus competencias (art. 36) mientras que para la provincia de nuevo encontramos una remisión a la legislación básica del Estado y a la de la Comunidad Autónoma (art. 47.2).

\section{Principios de la organización territorial}

Una de las novedades más significativas de los nuevos Estatutos de autonomía radica en la incorporación de una serie de principios que perfilan el carácter de la autonomía local. De esta manera, han sido estas normas institucionales básicas las que han incorporado a nuestro ordenamiento los principios presentes en la Carta Europea de Autonomía Local que hasta ahora habían sido ignorados por el legislador y durante muchos años también por la jurisprudencia.

De nuevo los Estatutos catalán y andaluz son los que con más profusión y densidad realizan esta labor. En concreto, el catalán recoge como principios de organización y funcionamiento de los municipios la plena capacidad de autoorganización, el derecho a asociarse con otros y a cooperar entre ellos y la plena capacidad normativa «como expresión del principio democrático en que se fundamentan, en el ámbito de sus competencias y en los otros sobre los que se proyecta su autonomía» (art. 87). Además ordena que las leyes que afecten al régimen jurídico, orgánico, funcional, competencial y financiero de los municipios deberá tener en cuenta las diferentes características demográficas, geográficas, funcionales, organizativas, de dimensión y de capacidad de gestión que tienen (art. 88). Este principio de diferenciación también se contempla en el EAA (art. 98.2), el cual también enumera como principios de la organización territorial de Andalucía los de autonomía, responsabilidad, cooperación, desconcentración, descentralización, subsidiariedad, coordinación, suficiencia financiera y lealtad institucional (art. 90), así como en el Estatuto balear cuando al remitir a una ley la regulación del régimen local señala que habrán de tenerse en cuenta las diferentes características de los municipios (art. 75.8).

El EAV se refiere a los principios de coordinación, colaboración y cooperación como regidores de las relaciones entre las administraciones públicas locales de la Comunitat Valenciana (art. 63.2). En este Estatuto se menciona de manera expresa el principio de subsidiariedad en dos ocasiones ${ }^{70}$. Por una par-

70 Como ha subrayado Francisco VELASCO, la referencia expresa al «principio de subsidiariedad» juega un
papel de «reequilibrio del poder territorial en el seno de las comunidades autónomas. El previsible aumento
de competencias autonómicas, por medio de la reforma estatutaria, habría de compensarse con una opción 
te, al hablar de la distribución de responsabilidades entre las diversas administraciones locales, la cual habrá de realizarse regida «por el principio de subsidiariedad, de acuerdo con lo que establece la Carta europea de autonomía local y por el principio de diferenciación, de acuerdo con las características que presenta la realidad municipal» (art. 64.2). Además, se anuncia la creación de un Fondo de Cooperación Municipal «para potenciar la autonomía local sobre la base del principio de subsidiariedad» (art. 64.3).

Dicho principio también se consagra, junto a los de proporcionalidad y diferenciación en el Estatuto aragonés (art. 85.1), el cual precisa que las relaciones entre la Administración de la Comunidad autónoma y las entidades locales se ajustarán a los criterios de información mutua, colaboración, coordinación y respeto a los ámbitos competenciales respectivos (art. 85.2).

El Estatuto de Castilla y León añade a los principios comunes al resto de estatutos (art. 43.2), la obligación de que la Comunidad y las entidades locales promuevan la cohesión y el equilibrio de todos sus territorios, con especial atención a las zonas periféricas y a las más despobladas y desfavorecidas (art. 43.3).

\section{Las comarcas y otras agrupaciones de municipios}

Los nuevos textos estatutarios también prestan atención a una de las cuestiones necesitadas de regulación más precisa. Me refiero a las diferentes fórmulas de agrupación de municipios, las cuales han ido adquiriendo en la práctica cada vez mayor peso y que en muchos casos pueden resultar imprescindibles para garantizar la prestación de determinados servicios así como la eficacia de la gestión en los municipios más pequeños.

En la mayoría de los Estatutos encontramos una remisión al legislador que deberá ser el que concrete las diferentes fórmulas asociativas. El Estatuto valenciano realiza en este sentido una proclamación muy genérica, remitiendo a una ley de Les Cortes «la creación de figuras asociativas entre las administraciones públicas para mejorar la gestión de los intereses comunes y para garantizar la eficacia en la prestación de los servicios» (art. 63.4). También se hace depender de una ley, que deberá ser aprobada por mayoría de dos tercios y después de ser consultadas las entidades locales afectadas, tanto la división comarcal (art. 65.1) como las áreas metropolitanas y las agrupaciones de comarcas (art. 65.3).

El Estatuto catalán incorpora la veguería como «el ámbito territorial específico para el ejercicio del gobierno intermunicipal de cooperación local», la cual

\footnotetext{
— también estatutaria - por la gestión administrativa en niveles locales». En todo caso, como el mismo autor apunta más adelante, la proclamación del principio de subsidiariedad no puedo afectar la distribución de poder entre Estado y Comunidades autónomas, ni tampoco alterar la posición constitucional de cada CA respecto de las provincias y municipios de su territorio. «Autonomía local y subsidiariedad en la reforma de los Estatutos de autonomía...», cit. Págs. 139 y 153.
} 
además es adoptada por la Generalitat como división territorial para la organización territorial de sus servicios (art. 90). El consejo y la administración autónoma de la veguería corresponde al Consejo de Veguería, el cual sustituye a la Diputación (art. 91). Tanto la creación de comarcas (art. 92) como de otros entes supramunicipales (art. 93) se remiten a una Ley del Parlamento.

El Estatuto andaluz aborda esta materia de manera un tanto reiterativa. Por un lado en su art. 94 remite a una regulación por ley las funciones de las «áreas metropolitanas, mancomunidades, consorcios y aquellas otras agrupaciones de municipios que se establezcan», para lo cual deberé tenerse presente el principio de «diferenciación» ${ }^{71}$. A su vez, el art. 98 remite a una ley las relaciones entre las instituciones de la Junta de Andalucía y los entes locales, así como «las técnicas de organización y de relación para la cooperación y la colaboración entre los entes locales» ${ }^{72}$. La creación de comarcas también se subordina a una ley, al acuerdo de los ayuntamientos afectados y a la aprobación del Consejo de Gobierno (art. 97).

El Estatuto balear se limita a reconocer el derecho de los municipios a asociarse con otros y a cooperar entre ellos, para lo que pueden constituir mancomunidades, consorcios y asociaciones (art. 75.7)

El Estatuto aragonés incluye las comarcas entre las entidades en que se organiza territorialmente la Comunidad (art. 81.1), las cuales «tienen a su cargo la prestación de funciones y servicios y la gestión de actividades de ámbito supramunicipal, representando los intereses de la población y territorio comarcales en defensa de una mayor solidaridad y equilibrio territorial» (art. 83.2).

La comarca se define también en el Estatuto de Castilla y León como posible «circunscripción administrativa de la Junta de Castilla y León para el cumplimiento de sus fines», debiendo formalizarse sus competencias por el legislador (art. 46.1 y 2). De manera expresa se menciona a la Comarca del Bierzo que será regulada por una ley específica que deberá tener en cuenta sus singularidades y trayectoria institucional (art. 46.3).

\section{Las provincias}

Una de las grandes cuestiones pendientes en nuestro sistema constitucional es la redefinición del papel de las provincias. Un papel que se ha ido difuminan-

\footnotetext{
71 Como bien ha señalado José Luis RIVERO, «éste es uno de los preceptos más vacíos del Estatuto» ya que ni define dichas entidades ni determina las potestades administrativas que van a tener. «El régimen local en el nuevo Estatuto de autonomía», cit. Pág. 857.

72 Estoy totalmente de acuerdo con la critica que realiza José Luis RIVERO a este precepto en la medida en que se reduce la futura Ley andaluza de Régimen Local a una simple ley de cooperación local, cuando dicho instrumento legislativo debería servir para unificar el régimen local andaluz. «El régimen local en nuevo Estatuto de autonomía de Andalucía», cit. Pág. 865.
} 
do a lo largo de estos treinta años, sobre todo por la fuerza expansiva de las administraciones autonómicas así como por la creación de agrupaciones de municipios que, bajo diferentes fórmulas, han cubierto buena parte de la labor que podría entenderse propia de las provincias ${ }^{73}$. Éstas han sobrevivido como divisiones territoriales heredadas de una etapa centralista y poco ajustadas a las necesidades de una estructura de poderes en la que no han conseguido situarse con éxito. Algo a lo que no ha contribuido ni el propio sistema de elección de los diputados provinciales ni su impreciso régimen competencial ${ }^{74}$.

El grado extremo de esta evolución estaría representado por el Estatuto catalán en el que, como hemos visto, la provincia ha venido a ser sustituida por la veguería, una opción discutida por parte de la doctrina ${ }^{75}$. El resto de Estatutos, algunos con más fortuna que otros, han tratado de precisar algo más el lugar de las provincias en el mapa territorial de su Comunidad, si bien ninguno ha ido más allá del papel que les ha asignado la jurisprudencia del Tribunal Constitucional.

El Estatuto valenciano ha potenciado la «interiorización» de las Diputaciones en la Generalitat, dejando muy claro que las mismas actuarán siempre como instituciones de la Comunidad y estarán sometidas a la legislación, reglamentación e inspección de ésta (art. 66.4). La Generalitat, mediante una ley, podrá transferir o delegar en ellas la ejecución de aquellas competencias «que no sean de interés general de la Comunitat Valenciana» (art. 66.2), además de que coordinará las funciones propias de las Diputaciones. A tales efectos, una ley apro-

\footnotetext{
73 Véase Mayte SALVADOR CRESPO, La autonomía provincial en el sistema constitucional español. Intermunicipalidad y Estado autonómico. INAP. Fundación Democracia y Gobierno Local. Madrid, 2007.

74 «Es necesario plantearse de una vez por todas una reforma Constitucional que, o suprima la Provincia como ente local necesario en toda España dejando como único escalón entre el Estado y el Municipio a la Comunidad Autónoma o, su alternativa, dote da la provincia de competencias propias y exclusivas en la gestión de los servicios supramunicipales en su territorio, lo que implica la coordinación de toda la administración instrumental municipal y demás entres supramunicipales o asociativos intermunicipales». José Luis RIVERO YSERN, «El régimen local en el nuevo Estatuto de Autonomía de Andalucía...», cit. Pág. 861.
}

75 Hay que tener en cuenta que si bien el Estatuto de autonomía también puede restringir parcialmente la autonomía provincial respecto de su configuración actual en la LBRL y en la jurisprudencia constitucional, dicha restricción tiene al menos tres límites constitucionales: la propia existencia de las provincias es indisponible; todos los municipios están integrados en alguna provincia y el respeto al «núcleo esencial» de la autonomía provincial. Francisco VELASCO, «Autonomía local y subsidiariedad...», cit. Pág. 132. Pueden plantearse problemas sobre todo con la posibilidad de la alteración de los límites provinciales, los cuales, establece el art. 91.4 EAC, «se va a llevar a cabo conforme a lo previsto en el art. 141 de la Constitución». Este artículo establece una reserva de ley orgánica para llevar a cabo dicha alteración. Por otra parte, el art. 151.b EAC al enumerar las competencias exclusivas sobre organización territorial se refiere sólo a la creación, supresión y la alteración de los términos de los municipios y las entidades locales de ámbito territorial inferior, pero no a las provincias. Además, esta competencia se atribuye a la Generalitat «respetando la garantía institucional establecida por la Constitución en los arts. 140 y 141». Por lo tanto, Cataluña tendría limitada la posibilidad de alterar los límites provinciales, al requerirse una ley orgánica. No se plantearían problemas en la medida en que las veguerías vinieran a coincidir con el territorio de las provincias a las que sustituyen. Sobre los problemas constitucionales que plantea esta cuestión véase Joseph MiR I BAGÓ, «La regulación de las veguerías en el nuevo Estatuto de Cataluña», Anuario de Gobierno Local, 2006. Págs. 79-104. 
bada por mayoría absoluta establecerá las fórmulas de coordinación. Para facilitar ésta, los presupuestos de las Diputaciones se unirán a los de la Generalitat (art. 66.4). Ésta ostenta a su vez un doble poder coactivo sobre las Diputaciones (art. 66.5): $1 .^{\circ}$ ) Si éstas no cumplen las obligaciones impuestas por el Estatuto o la Ley, el Consell, previo requerimiento al Presidente de la Diputación de que se trate, podrá adoptar las medidas necesarias para forzar a dicho cumplimiento; . $^{\circ}$ ) Les Corts, por mayoría absoluta, podrán revocar la delegación de la ejecución de aquellas competencias en las que la actuación de las Diputaciones atente al interés general de la Comunitat.

El Estatuto andaluz también subraya el papel de la Junta de Andalucía en la coordinación de la actuación de las Diputaciones «en materias de interés general para Andalucía». La apreciación del interés general y las fórmulas de coordinación se establecerán por una ley aprobada por mayoría absoluta del Parlamento de Andalucía. En todo caso, le corresponde a la Junta de Andalucía la coordinación de los planes provinciales de obras y servicios (art. 96.4) ${ }^{76}$. Previamente, el EAA hace un esfuerzo de delimitación de las competencias provinciales, incidiendo en su subordinación a la Comunidad Autónoma ${ }^{77}$.

Mucho más escueto es el Estatuto aragonés, que se limita a definir la provincia como entidad supramunicipal con funciones de cooperación, asistencia y prestación de servicios a municipios y comarcas (art. 84). Poco más añade el de Castilla y León, que insiste en que constituyen divisiones territoriales para el cumplimientos de los fines de la Comunidad (art. 47.1) y en que su papel fundamental es el de cooperación y asistencia a los municipios (art. 47.2). Este artículo se cierra con la previsión de que las provincias pueden prestar servicios supramunicipales de carácter provincial, en el ámbito de las competencias locales, «sin perjuicio de las que puedan delegarle o encomendarle las entidades locales de su ámbito territorial o la Comunidad autónoma». No queda muy claro en este caso de qué manera y bajo que fórmula jurídica podrán los ayuntamientos proceder a dicha encomienda o delegación en las Diputaciones.

\footnotetext{
76 Como ha puesto de manifiesto Gerardo RUIZ-RICO, esta regulación es menos respetuosa con la autonomía provincial ya que el art. 96.4 extiende la coordinación de la Junta a todas las competencias atribuidas a las provincias. En la anterior redacción, el art. 4.5 limitaba esa facultad de coordinación a las competencias «que con carácter específico y para el fomento y la administración de los intereses peculiares de la provincia le vengan atribuidas por la legislación básica del Estado y la legislación que dicte la Comunidad Autónoma en desarrollo de la misma.» Gerardo RuIZ-RICO, «Las entidades locales en la proposición de reforma del Estatuto de autonomía de Andalucía», cit. Pág. 73.

77 De manera bastante insatisfactoria el art. 96.3 incluye entre ellas: a) La gestión de las funciones propias de coordinación municipal, asesoramiento, asistencia y cooperación con los municipios, especialmente los de menor población que requieran de estos servicios, así como la posible prestación de algunos servicios supramunicipales, en los términos y supuestos que establezca la legislación de la Comunidad Autónoma; b) Las que con carácter específico y para el fomento y la administración de los intereses peculiares de la provincia le vengan atribuidas por la legislación básica del Estado y por la legislación que dicte la Comunidad Autónoma en desarrollo de la misma; c) las que pueda delegarle para su ejercicio la Comunidad autónoma, siempre bajo su dirección y el control de ésta.
} 


\section{6. Órganos de relación entre los entes locales y las Comunidades Autónomas}

Una de las críticas reiteradas al sistema de articulación entre los tres poderes del Estado ha sido la prácticamente nula presencia de los entes locales en los procesos de toma de decisiones que les afectan. Una exigencia a la que también hace referencia expresa la CEAL: «Las Entidades locales deben ser consultadas, en la medida de lo posible, a su debido tiempo y de forma apropiada, a lo largo de los procesos de planificación y de decisión para todas las cuestiones que les afectan directamente» (art. 4.6). Este déficit ha tratado de solucionarse, al menos en parte, con la previsión en los nuevos Estatutos de órganos a través de los cuales la voluntad de los entes locales puede hacerse presente en los procesos decisorios autonómicos ${ }^{78}$. Siguiendo muy de cerca la reciente experiencia italiana, estos órganos presentan diferentes perfiles en cada Comunidad Autónoma. Su virtualidad va a depender en gran medida del papel que la voluntad política mayoritaria quiera otorgarle en cada momento. Los nuevos Estatutos de Autonomía, si bien difieren en la de denominación y estructura de este tipo de órganos, coinciden en atribuirles como función principal la de informar preceptivamente las iniciativas legislativas que afecten de manera específica a las entidades locales así como la tramitación de planes y normas reglamentarias de idéntico carácter.

El Estatuto valenciano contiene una referencia muy genérica a una Comisión Mixta entre la Generalitat y Provincias como órgano deliberante y consultivo para determinar las bases y métodos que favorezcan las bases de participación en dichas instituciones (art. 68.4). Esta estructura mixta también es la que se contempla en el Estatuto andaluz (art. 95) y en el de Castilla y León (art. 51). En el caso del Consejo de Cooperación Local de Castilla y León se exige que las Corporaciones locales estén representadas «con criterios que aseguren la pluralidad política, territorial e institucional».

El Estatuto aragonés no deja muy claro si opta por un órgano de carácter mixto, ya se refiere al Consejo local de Aragón definiéndolo como «órgano de colaboración y coordinación entre el Gobierno de Aragón y las asociaciones representativas de las entidades locales aragonesas» (art. 86).

Sólo el Estatuto Catalán apuesta por que el Consejo de Gobierno Locales como un órgano de representación exclusiva de los municipios y veguerías en las instituciones de la Generalitat (art. 85) ${ }^{79}$. Esta opción es la que mejor puede

\footnotetext{
78 Debemos recordar que en Murcia ya se había regulado mediante la ley 9/1994, de 30 de diciembre, el denominado Consejo Regional de Cooperación Local, contemplado como un órgano de carácter deliberante y consultivo, de composición mixta y encargado de emitir informes en asuntos que afecten a las entidades locales, tales como anteproyectos de leyes y proyectos de reglamentos, atribuciones o delegaciones de competencias o previsiones de los presupuestos que afecten a dichas entidades.
}

79 Véase M. Vilalta ReiXach, El Consejo de Gobiernos Locales. Iustel. Madrid, 2007. 
garantizar la representación de los intereses de las entidades locales ${ }^{80}$. La fórmula mixta incide negativamente en la capacidad de expresión política de dichas entidades y reduce la actuación de estos órganos a un filtro más en los procedimientos legislativos o en la elaboración de planes, condicionado por la negociación política que se lleve a cabo entre los grupos políticos. Es decir, más que la voluntad de los entes locales lo que estos órganos acabarán expresando será un «consenso negociado» y condicionado por las mayorías políticas dominantes en cada momento ${ }^{81}$.

\section{La financiación de los entes locales}

Uno de los principales problemas de los municipios españoles, tal vez el principal, a lo largo de estos treinta años ha sido su insuficiente financiación. Un problema que se ha ido agravando a medida que han ido creciendo las competencias que la legislación sectorial les ha ido atribuyendo. De ahí que en las reformas estatutarias se haya prestado una especial atención a la vinculación de atribución de competencias y suficiencia financiera, de manera que la denominada «segunda descentralización» no se convierta más en un problema que en una oportunidad para los entes locales. Todos los nuevos Estatutos coinciden en la previsión de que cualquier descentralización de competencias en los Ayuntamientos debe ir acompañada de los recursos económicos para que sea efectiva (art. $64 \mathrm{EAV}$, art. 93.1 EAA, art. 75.5 EAB, art. 85.3 EAR, art. 50.1 ECL). El Estatuto catalán lo expresa de manera más precisa: «La Generalitat debe deter-

\footnotetext{
80 En el caso catalán habría también que tener presente el papel que puede desempeñar en cuanto a la protección de la autonomía local del «polémico» Consejo de Garantías Estatutarias. Hay que tener en cuenta que, entre otras funciones, el art. 76.2 EAC le asigna la de dictaminar sobre «la adecuación de los proyectos y las proposiciones de ley y de los proyectos de decreto legislativo aprobados por el Gobierno a la autonomía local en los términos que garantiza el presente Estatuto». Además debe dictaminar antes de la interposición del conflicto en defensa de la autonomía local.

81 El legislador andaluz es el único que de momento ha regulado este tipo de órganos. En concreto, la Ley 20/2007, de 27 de diciembre, creó el denominado Consejo Andaluz de Concertación Local, el cual celebró su sesión constitutiva en junio de 2008. El art. 2 de dicha ley lo define como «un órgano colegiado permanente, de carácter deliberante y consultivo, de la Junta de Andalucía, adscrito a la Consejería competente en materia de Administración Local». El mismo artículo deja muy claro que la consulta a este órgano será preceptiva en los casos establecidos en el artículo siguiente o en otras disposiciones de igualdad rango, y facultativa en el resto, «no siendo vinculantes sus dictámenes, salvo que así se determine expresamente». En cuanto a su composición el art. 5 de la ley dispone que será paritaria, con presencia equilibrada de hombres y mujeres y con representación de la Administración de la Junta de Andalucía y de la Administración Local. En concreto, y en representación de la primera, participarán la persona titular de la Consejería competente en materia de Administración Local; ocho vocales designados por el Consejo de Gobierno de la Junta de Andalucía y la persona titular de la Dirección General competente en materia de Administración Local. En representación de la Administración local, lo harán la persona titular de la Presidencia de la asociación de municipios y provincias de carácter autonómico de mayor implantación y ocho vocales, cuya designación se realizará por el órgano competente de la citada asociación. El predominio de la Junta de Andalucía en esta composición mixta se pone de manifiesto en que la presidencia del Consejo corresponderá a la persona titular de la Consejería competente en materia de Administración Local. (art. 6.1). Este Presidente o Presidenta dispone a su vez de voto de calidad para resolver los empates que se produzcan en la adopción de acuerdos que, según el art. 11, requerirán el voto favorable de la mayoría de miembros del Consejo.
} 
minar y fijar los mecanismos para la financiación de los nuevos servicios derivados de la ampliación del espacio competencial de los gobiernos locales» (art. 84.4). Este principio se regula de manera mucho más completa en un largo artículo, el 219, contenido en el capítulo III del Título VI, dedicado a las haciendas locales, y que lleva por título «Suficiencia de recursos» ${ }^{82}$. Dicho capítulo regula la autonomía financiera y de gasto de las entidades locales (art. 118), a las que se reconoce la capacidad para regular sus propias finanzas en el marco de las leyes y para gestionar, recaudar e inspeccionar sus tributos, «sin perjuicio de que puedan delegarla a la Generalitat y de que puedan participar en la Agencia Tributaria de Cataluña». La Generalitat tiene competencia, en el marco establecido por la Constitución y la normativa del Estado, en materia de financiación local y le corresponde el ejercicio de la tutela financiera sobre los gobiernos locales, «respetando la autonomía que les reconoce la Constitución». Además se remite al Parlamento la aprobación de una ley de haciendas locales, encargada de desarrollar los anteriores principios y en la que se prevea que las facultades atribuidas a la Generalitat deben ejercerse con respecto a la autonomía local y oído el Consejo de Gobiernos Locales (art. 220). El capítulo finaliza con un artículo dedicado al catastro en el que se indica la necesidad de establecer formas de gestión consorciada del Catastro entre el Estado, la Generalitat y los municipios, de acuerdo con lo que disponga la normativa del Estado y de manera tal que se garantice la plena disponibilidad de las bases de datos para todas las Administraciones y la unidad de la información (art. 221).

El Estatuto andaluz prácticamente copia las previsiones del catalán en la Sección Tercera del capítulo III del Título VI, partiendo de una serie de principios que deben regir las haciendas locales andaluzas: suficiencia de recursos para la prestación de los servicios que les corresponden, autonomía, responsabilidad fiscal, equidad y solidaridad (art. 191.1). Se prevé la participación de las entidades locales en los tributos de la Comunidad Autónoma, que se instrumen-

\footnotetext{
82 En concreto, en este artículo se realizan las siguientes previsiones: 1. El establecimiento por parte de la Generalitat de un fondo de cooperación local destinado a los gobiernos locales, el cual debe ser regulado por ley y dotarse a partir de todos los ingresos tributarios de la Generalitat; 2. Los ingresos de los gobiernos locales consistentes en participaciones en tributos y en subvenciones incondicionadas estatales son percibidos por medio de la Generalitat, que los debe distribuir de acuerdo con lo dispuesto en la Ley de Haciendas Locales de Cataluña, cuya aprobación requerirá mayoría de $3 / 5$, y respetando los criterios establecidos por la legislación del Estado en la materia. En el caso de las subvenciones incondicionadas, estos criterios deberán permitir que el Parlamento pueda incidir en la distribución de los recursos con el fin de atender a la singularidad del sistema institucional de Cataluña; 3. La garantía a los gobiernos locales de los recursos suficientes para hacer frente a la prestación de servicios cuya titularidad o gestión se les traspase o delegue. Toda nueva atribución de competencias debe ir acompañada de los recursos suplementarios para financiarlas correctamente, de modo que se tenga en cuenta la financiación del coste local y efectivo de los servicios prestados. El cumplimiento de este principio, marca el EAC, «es una condición necesaria para que entre en vigor la transferencia o delegación de la competencia»; 4. La distribución de recursos procedentes de subvenciones incondicionadas o de participaciones genéricas en impuestos debe llevarse a cabo teniendo en cuenta la capacidad fiscal y las necesidades de gasto de los gobiernos locales y garantizando en todo caso su suficiencia; 5. La distribución de los recursos entre los gobiernos locales no puede comportar en ningún caso una minoración de los recursos obtenidos por cada uno de éstos, según los criterios utilizados en el ejercicio anterior a la entrada en vigor de los preceptos del Estatuto.
} 
tará a través de un fondo de nivelación municipal, de carácter incondicionado (art. 192.1). Se insiste en la suficiencia de recursos de dichas entidades mediante previsiones como que cualquier modificación del marco normativo de la Comunidad Autónoma que disminuya los ingresos locales habrá de prever la compensación oportuna (art. 192.6) o que cualquier atribución de competencias ha de ir acompañada de la asignación de recursos suficientes (art. 192.7) ${ }^{83}$.

El Estatuto balear sólo dedica el apartado 9 del art. 75 a esta cuestión. En él de manera resumida se contienen todos los principios recogidos en los demás textos estatutarios. Sí dedica todo un capítulo, el IV del Título IX, a la financiación y las haciendas de los Consejos insulares.

También de manera mucho más breve se regula esta materia en el nuevo art. 70 del Estatuto valenciano, así como las relaciones financieras de las entidades locales aragonesas (art. 114 EAR) y los criterios reguladores de las haciendas locales de Castilla y León (capítulo III del Título III). Cabe destacar que en este último caso se dispone que la Comunidad Autónoma debe velar por el cumplimiento de los principios de suficiencia de recursos, equidad, autonomía y responsabilidad fiscal así como «por la corrección de desequilibrios económicos entre las entidades locales, con el fin de garantizar la igualdad en el acceso a los servicios públicos locales a todos los ciudadanos de la Comunidad» (art. 53).

\section{CONCLUSIONES}

A pesar de los avances que suponen las previsiones de los nuevos Estatutos de autonomía, nuestro régimen local sigue en una situación de provisionalidad y no se ha incorporado con voz propia al debate sobre las autonomías territoriales. Sigue faltando una coordinación de estos procesos con una revisión de la legislación básica estatal y, en definitiva, una eficaz protección de la autonomía local entendida como uno de los tres términos en que se organiza territorialmente el Estado español. Los nuevos Estatutos suponen un importante avance en lo que parte de la doctrina ha denominado «fase autonómica del Pacto Local», pero requieren no sólo de un oportuno desarrollo por parte de los legisladores autonómicos sino también de una redefinición del espacio local por el legislador estatal. Esta redefinición debería tener presentes los siguientes retos:

1..$^{\circ}$ Habría que introducir en la misma Constitución una noción de autonomía local mucho más ajustada a los tiempos en que vivimos y a la propia evolución de nuestro sistema territorial. Como mínimo, sería necesario incor-

83 Como bien ha señalado Francisco VELASCO, la eficacia de estas garantías de suficiencia financiera es menor de lo que aparentan. Sólo serán eficaces «cuando las leyes tributarias carezcan de toda medida de compensación como consecuencia de la supresión o alteración de un tributo local; o cuando la atribución de una nueva competencia suponga un incremento relevante del gasto municipal sin que al mismo tiempo se haya dispuesto una financiación específica». «El estatuto de autonomía local en 2007», cit. Pág. 28. 
porar tres grandes cuestiones ${ }^{84}:$ a) La definición de la autonomía local como una competencia compartida entre el Estado y las CC.AA.; b) La habilitación a una Ley Orgánica de bases de gobierno y administración local, de la que se subraye su «función constitucional» de desarrollo y concreción de la autonomía local. Dicha Ley, como ha propuesto Tomás Font, debería concretar el contenido «mínimo» de la autonomía local, mientras que el legislador estatutario establecería el contenido «óptimo» para su propio territorio ${ }^{85}$; c) La introducción de los principios básicos de la Carta Europea de Autonomía Local, fundamentalmente los de subsidiariedad, proporcionalidad y diferenciación ${ }^{86}$. Todo ello permitiría la concreción de lo que parte de la doctrina ha venido en llamar «bloque de la constitucionalidad local» ${ }^{87}$, despejaría las dudas en torno a la posición de la LRBRL y se traduciría no sólo en una más eficaz protección de la autonomía local sino también en una más sensata articulación de nuestro modelo territorial.

Estos principios deberían ir acompañados de una reforma del «conflicto en defensa de autonomía local», del que habría que revisar los criterios de legitimación activa. Es necesario reducir el número de entidades necesarias para plantearlo así como legitimar a la asociación de entidades locales con mayor implantación en el ámbito territorial de aplicación de la disposición cuestionada para la interposición directa del conflicto. Hay que tener en cuenta que tras las recientes reformas estatutarias los municipios cuentan con contenidos más precisos de definición del canon constitucional de autonomía local y por tanto con garantías más eficaces frente a leyes estatales y autonómicas que puedan lesionar su autonomía. Además cabría plantearse la personación de dichas asociaciones en los procesos de inconstitucionalidad en los que se haya puesto en cuestión una ley que afecte a los intereses locales.

2. ${ }^{\circ}$ ) Debe plantearse un nuevo esquema de relaciones entre la legislación básica y la autonómica, de tal manera que la eficacia de la primera será más limitada en aquellas Comunidades que hayan asumido de manera plena la competencia exclusiva sobre régimen local ${ }^{88}$. La LRBRL cumpliría pues una fun-

84 Comparto plenamente las propuestas de Javier GARCÍA ROCA, «La primera sentencia constitucional sobre el conflicto en defensa de la autonomía local...», cit. Pág. 23.

85 Tomás FonT i LlOVET, «Autonomía local y Estatutos : crónica de un compromiso», cit. Pág. 28.

86 El principio de subsidiariedad ha de jugar un papel esencial tanto en la distribución de las competencias como en su aplicación. Por su parte, la proporcionalidad jugaría en el sentido de dotar a los municipios de un margen de actuación suficiente y por tanto como limitación de las acciones normativas tanto estatales como autonómicas. Sobre estos principios véase Javier GARCÍA ROCA, «Un bloque constitucional local conforme al principio de subsidiariedad...», cit. Págs. 48-54.

87 Véase Ana M. a DE LA VEGA DE DÍAZ RICCI, La autonomía municipal y el bloque constitucional local: Un estudio de Derecho argentino y español. Ciudad Argentina. Buenos Aires, 2006.

88 «El Estatuto ha de interpretar, antes de nada, lo que la Constitución ha reservado (por básico) al Estado. Luego, cada Estatuto ha de decidir - a la vista de la singularidad de cada comunidad - hasta dónde ha de llegar la competencia de desarrollo: si ocupar todo el espacio no reservado al Estado o si ocupar sólo una función de complemento normativo ejecutivo. O, incluso, ninguna función normativa ad extra. Enton- 
ción de «mínimo normativo» de acuerdo con la regulación que se contenga en cada Estatuto de autonomía ${ }^{89}$. En el caso de dos normas concurrentes será aplicable la que contenga un «estándar más elevado» de autonomía local.

La legislación básica estatal debería reducirse pues a unos principios mínimos, correspondiendo su desarrollo a los Estatutos de autonomía, los cuales deben adaptar las entidades locales a las especificidades de cada nacionalidad y región ${ }^{90}$. La Ley de Bases ha de limitarse a «garantizar los mínimos competenciales que dotan de contenido y efectividad la garantía de la autonomía local (SSTC 214/89, FJ 3. ${ }^{\circ}$; 159/2001, FJ 4. ${ }^{\circ}$ ). Por lo tanto, ha de evitar la tendencia excesivamente «uniformizadora» que hasta el presente ha dominado nuestro régimen local y debe dejar espacios tanto al desarrollo por el legislador autonómico como a la capacidad de auto-organización de los municipios. En este sentido, debe otorgársele al Reglamento Orgánico Municipal un espacio similar al que inicialmente le posibilitaba el art. 5 LRBRL. Ello permitirá adaptar la organización municipal a las demandas y necesidades del complejo y diverso mapa municipal español ${ }^{91}$. Como criterios de diferenciación habría que tener presentes no sólo el número de habitantes, sino también la capacidad económica o de gestión de cada municipio, así como también su voluntad de asumir determinadas competencias ${ }^{92}$.

3. ${ }^{\circ}$ En íntima relación con este reajuste organizativo habría que situar a los entes locales intermedios cuya función principal sería la de apoyar y asistir a aquellos municipios que por sí solos tienen dificultades para la prestación de determinados servicios o en general para el cumplimiento de las funciones

ces, es claro que los confines de la competencia estatal básica dependerán —en cada comunidad autónoma - de lo que establezca cada Estatuto». Francisco VELASCO, «Estatutos de autonomía, leyes básicas...», cit. Pág. 140.

89 Francisco Velasco, El régimen local en la reforma de los Estatutos de Autonomía, cit. Pág. 50. Como este mismo autor señala, el distinto alcance de lo básico es una consecuencia de la forma constitucional de España. «Estatutos de autonomía, leyes básicas y leyes autonómicas en el sistema de fuentes del Derecho local», cit. Pág. 138.

90 Francisco CAAMAÑo propone que las bases estatales se reduzcan a la regulación no del gobierno local, sino del régimen jurídico de su actividad administrativa. La organización municipal debería corresponder al legislador autonómico y en ambos casos, organización y administración, tanto el Estado como las CC.AA. carecen de competencias de ejecución. «Autonomía local y Constitución...», cit. Pág. 185.

91 En este sentido, estoy de acuerdo con Francisco VELASCO el cual insiste en que en los últimos años se está sustituyendo la «autodiferenciación» por la «heterodiferenciación», es decir, la necesaria diferenciación en el régimen de los distintos municipios se lleva a cabo a través de leyes del Estado o de leyes de las Comunidades Autónomas, reduciéndose la capacidad de autonomía organizativa de los municipios. «El estado de la autonomía local en 2007», cit. Pág. 43.

92 El Anteproyecto de LGAL suponía un paso adelante en la reducción de la normativa básica y en la apertura de mayores posibilidades organizativas de las entidades locales. De esta manera, se corregía el excesivo uniformismo que ha caracterizado durante estos treinta años el régimen local y se permitía una mejor adaptación a las dimensiones y singularidades de cada municipio. Así, cabe destacar como se incorporaba una norma denominada Estatuto local, aprobada por el Pleno, y que tendría por objeto la regulación de su organización y funcionamiento, de los órganos complementarios, los órganos y procedimientos de participación ciudadana y los principios y criterios esenciales de los órganos integrados en el ámbito del ejecutivo local. 
que la legislación les asigna ${ }^{93}$. En esta dirección habría igualmente que redefinir el papel de las Diputaciones provinciales, cuyo ámbito de actuación dependerá en gran medida de la implantación real que las mismas tengan en cada Comunidad. Lo que no tiene sentido es mantener las Diputaciones con los «lastres y adherencias del pasado» ni tampoco superponer en un mismo espacio entes intermedios con similares cometidos. ${ }^{94}$ Junto a una más precisa definición de sus funciones, que deberían fomentar la «intermunicipalidad», sería conveniente revisar el sistema de elección de los diputados y diputadas provinciales que, en muchos casos, propicia la aparición de una clase política clientelar y escasamente cualificada. Habría que revisar que el partido judicial sea la referencia para su designación y habría en todo caso que asegurar la participación efectiva de los municipios en las políticas impulsadas por la diputación. Ésta debería ejercer las competencias que los municipios, por falta de capacidad administrativa o de gestión, no sean capaces de ejercitar ${ }^{95}$. Igualmente debería corresponderle a la provincia, o bien a algún ente local intermedio, los asuntos intermunicipales que no pueden ser desempeñados de forma aislada por los municipios (por ejemplo, transporte público comarcal, carreteras y caminos comarcales, planeamiento plurimunicipal) pero que tampoco presentan un interés autonómico. Habría que precisar sus funciones de cooperación y asistencia - financiera, técnica, de personal- y no limitarse a otorgar subvenciones, en la mayoría de los casos con evidentes condicionantes «partidistas», y en el peor de los casos a convertirse en un gobierno «de oposición» frente al de la capital cuando ambos responden a mayorías políticas distintas. Si la provincia no cumple el papel de interlocución y de creación de «redes» que faciliten una mejor gobernanza local, mejor sería plantearse su misma existencia ${ }^{96}$.

93 El Anteproyecto LBGAL no era especialmente generoso en esta materia. Las relaciones intermunicipales no merecieron ni un capítulo específico. Aparecían integradas en las Disposiciones Generales del Título I, en el que se contenían unas referencias muy genéricas a las «mancomunidades de municipios» (art. 4) y las asociaciones de entidades locales para la promoción y defensa de intereses comunes (art. 5).

94 Francisco CAAMAÑo DomíngueZ, «Autonomía local y Constitución...», cit. Págs. 187-188.

95 Es la función que se esforzaba en otorgarle el Anteproyecto LBGAL. Por ejemplo, cuando se señalaban los servicios obligatorios municipales se preveía que las CC.AA., por medio de las diputaciones y a través de las fórmulas de intermunicipalidad que consideren más idóneas, pudieran graduar el cumplimiento o dispensa de dichos servicios de acuerdo con criterios como la población, la calidad de la servicios, la capacidad técnica y económica o la extensión territorial de los municipios (art. 23.1).

96 En este sentido, el Anteproyecto LBGAL dejaba muy claro que la función de la provincia sería asegurar «la prestación integral y adecuada en la totalidad del territorio de los servicios de competencia municipal para garantizar la prestación universal a todos los ciudadanos, generando economías de escala que propicien una mayor calidad, eficacia y eficiencia en dicha prestación» (art. 25.1). De ahí que se concretasen como competencias propias de la provincia y de la isla: a) la asistencia y cooperación jurídica, económica, técnica, administrativa y de gestión a los municipios, dirigida a garantizar el ejercicio íntegro de sus competencias y servicios; b) la ejecución de obras y equipamientos y la prestación de servicios públicos de carácter municipal, intermunicipal o de interés provincial o insular; c) El apoyo a las políticas municipales de su territorio. A estas competencias habría que sumar las de cooperación con los municipios mediante planes o programas «en cuya elaboración participan éstos, fijando sus prioridades, en el marco del respeto a los siguientes principios: a) Garantía de la solidaridad y el equilibrio intermunicipales, en el marco de la política social y económica; 
4..$^{\circ}$ Desde el punto de vista del sistema de gobierno municipal, no creo que sean necesarias reformas sustantivas, más allá de consolidar su progresiva «parlamentarización» y permitir ciertas diferencias organizativas en función del tamaño del municipio ${ }^{97}$. En todo caso, el legislador básico estatal debería garantizar un «estatuto de la oposición» que permita el adecuado desenvolvimiento de la función de control de la mayoría gobernante, así como un más completo y detallado «estatuto de los electos locales» que permita el correcto desenvolvimiento de los derechos inherentes a estos cargos públicos representativos ${ }^{98}$.

Pese a las numerosas propuestas planteadas en la década de los noventa en torno a la reforma del sistema electoral local, no creo que el momento actual demande un cambio sustancial en el mismo ${ }^{99}$. Ni tan siquiera la reiterada propuesta de elección directa de los alcaldes, impulsada en la década de los noventa por referentes comparados que no siempre han provocado los efectos esperados, ofrece argumentos que avalen una mejora sustancial de la vida política local o una reducción de la inestabilidad en los Ayuntamientos que, por otra parte, no es tan alarmante como a veces las referencias mediáticas muestran. Creo que es más conveniente garantizar en un más equilibrado funcionamiento de los mecanismos parlamentarios de los ayuntamientos que ensayar fórmulas distintas de elección de consecuencias inciertas ${ }^{100}$. En este terreno sólo cobra

\footnotetext{
b) Creación, gestión y mantenimiento de redes de servicios municipales, en las que se integran los municipios con carácter voluntario; c) Planificación y programación anual o plurianual; d) Sostenibilidad económica, social y medioambiental en los equipamientos, infraestructuras y servicios afectados.
}

97 En esta dirección, el Anteproyecto LBGAL no introducía novedades significativas, limitándose a consolidar el «modelo parlamentario» de tal manera que quedasen perfectamente delimitadas las funciones del «ejecutivo municipal» (Alcalde y el Consejo de Gobierno, previsto para los municipios de más de 75.000 habitantes y en aquellos en que así lo decida el Alcalde mediante decreto de organización) y las del Pleno, encargado básicamente de dos funciones: $1 .^{\circ}$ ) La aprobación del Estatuto municipal, de las ordenanzas y de los Presupuestos; $2 .^{\circ}$ ) el control y fiscalización de los órganos de gobierno.

98 El Anteproyecto LBGAL dedicaba todo un capítulo al estatuto de los cargos representativos locales, en el que concretaba sus derechos políticos y económicos (arts. 59 y 61), sus deberes, responsabilidades e incompatibilidades (art. 62), la obligación de registrar sus intereses y bienes (art. 63) así como las funciones de los grupos políticos (art. 64). No se introducía ninguna novedad con respecto a los concejales «tránsfugas», manteniendo la regulación de los miembros «no adscritos» introducida por la Ley 57/2003.

99 El Libro Blanco se mostraba muy cauto en esta materia. En él se afirmaba que «el sistema electoral local garantiza en grado suficiente la representación del pluralismo político y la gobernabilidad de las instituciones locales». Además apuntaba la necesidad de sopesar cuidadosamente las ventajas e inconvenientes de la elección directa del Alcalde. Partiendo de estas cautelas, se proponían unas leves reformas del sistema: ampliar hasta los municipios con 1000 residentes el sistema mayoritario plurinominal que ya existe en los que tienen entre 100 y 250 residentes, y en los que sería designado alcalde el concejal que más votos populares directos hubiera obtenido; mientras que en los de más de 1.000 habitantes, sería elegido alcalde directamente el cabeza de lista que hubiera obtenido la mayoría absoluta de los sufragios. El Libro Blanco planteaba, de manera muy cauta, el estudio de la posibilidad de que varias listas se vinculasen previamente a la elección, en el sentido de que comunicasen a la administración electoral que apoyan al cabeza de la lista más votada entre las vinculadas. Una vinculación que habría que comunicar a la Administración electoral y que debería figurar en la papeleta electoral. Finalmente, el Libro Blanco sugería que las segundas vueltas sólo deberían ser introducidas en las «grandes ciudades».

100 Sin embargo, son muchas las opiniones en contra de este criterio. Sirva como ejemplo la de Pablo SANTOLAYA MACHETTI, el cual insiste en que «si pretendemos la estabilidad de los Ayuntamientos para que 
cada día más urgencia la necesidad de extender el derecho de sufragio a los residentes en el municipio con independencia de que tengan o no la nacionalidad española. En esta cuestión, la mayor dificultad estriba en la exigencia de reciprocidad planteada por el art. $13 \mathrm{CE}$.

Por otra parte, sería conveniente reforzar los mecanismos de participación ciudadana en el ámbito local. Este constituye el más apropiado para desarrollar instrumentos que complementen los representativos. La legislación básica estatal y también la autonómica de régimen local debería limitarse a establecer unos principios y unas pautas muy generales, dejando en manos de los Reglamentos orgánicos municipales la concreción de los órganos y procedimientos que se adecuen a las características de cada pueblo o ciudad ${ }^{101}$. En todo caso, debería garantizarse la participación de las asociaciones de vecinos, así como en las más representativas de los diversos intereses ciudadanos, en órganos no meramente consultivos y en los procedimientos de elaboración de normas municipales, reconociéndose su capacidad para plantear iniciativas o propuestas en el Pleno. El legislador debería además garantizar que los órganos que canalicen la participación vecinal no están mediatizados por los partidos, de manera que el nombramiento de sus miembros y de su presidencia corresponda a los mismos vecinos y no a unas «elites» dependientes de los grupos políticos de la Corporación. Además estos instrumentos participativos deben posibilitar que la voluntad expresada por los vecinos incida realmente en las políticas locales, de lo contrario conseguirán un efecto perverso: la frustración de las expectativas ciudadanas con el consiguiente deterioro de unos instrumentos condenados a la manipulación y a la invisibilidad. El desarrollo de estos mecanismos de participación puede facilitarse mediante el uso de nuevas tecnologías, que permitirán con más facilidad la realización de encuestas o consultas, así como el fomento de la participación de entidades, organizaciones y asociaciones sin ánimo de lucro en el ejercicio de competencias municipales.

5..$^{\circ}$ Es urgente clarificar el espacio competencial local, tal y como ya han empezado a realizar los Estatutos de Autonomía ${ }^{102}$. También en este caso la Ley básica estatal debería superar la técnica consistente en dejar en manos de la legislación sectorial la concreción de las competencias locales (arts. 25 a 28 LR$\mathrm{BRL}$ ). Dicha ley debería incorporar los principios que deben presidir el régi-

puedan desarrollar sus políticas públicas, hemos de trabajar en la óptica de la elección directa de los Alcaldes, o bien, introducir en el sistema actual considerables primas mayoritarias para los partidos que en cada municipio ganen las elecciones». «Encuesta sobre el régimen electoral», Teoría y realidad constitucional, N. ${ }^{22}$, 2008. Pág. 56.

101 Era la opción del Anteproyecto LBGAL, el cual remitía a los Estatutos municipales la regulación de los procedimientos y órganos adecuados «para el fomento y la efectiva participación de los vecinos en los asuntos de la vida pública local» (art. 18.1)

102 El Libro Blanco proponía como objetivo la gestión por la Administración local de cómo mínimo un 25\% del sector público a nivel de cada Comunidad Autónoma. 
men competencial (autonomía, subsidiariedad, proporcionalidad, flexibilidad) así como un listado de competencias mínimas y propias, así como un segundo en el que se contemplaran competencias delegables ${ }^{103}$. Igualmente habría que introducir una ordenación de las competencias concurrentes. Junto a estas previsiones, debería incluirse una cláusula general mediante la cual se atribuyese a los municipios la capacidad para actuar en todos los ámbitos no reservados a otras administraciones. A partir de esos «mínimos», la determinación última de las competencias locales quedaría en manos del legislador autonómico.En todo caso, las leyes sectoriales que incidiesen en intereses locales deberían justificar expresamente la concurrencia de intereses estatales o autonómicos que legitimaran la atribución de la competencia a la Administración estatal o de la Comunidad Autónoma ${ }^{104}$.

El sistema de atribución de competencias debería tener en cuenta no sólo el criterio de la población sino también la capacidad de gestión de cada una de las entidades locales, de tal forma que si un municipio no pudiera ejercer de mane-

103 El Libro Blanco realizaba una propuesta muy oportuna de este ámbito mínimo de competencias municipales a la que me remito. De manera esquemática, se proponían los siguientes bloques competenciales: a) Competencias relativas al desarrollo y funcionamiento internos de la organización municipal; b) Competencias relativas a las relaciones del ayuntamiento con los ciudadanos; c) Competencias relativas a la determinación y gestión de los ingresos y a la disposición de los gastos, d) Competencias relativas a la disposición y gestión de los bienes competenciales; e) Competencias relativas a la ordenación, protección y control de los usos de que pueda ser objeto el territorio municipal; f) Competencias relativas a la ordenación y control de las actividades desarrolladas en el municipios; g) Competencias relativas a la seguridad y protección de la colectividad local; h) Competencias relativas al establecimiento y gestión de los servicios urbanos; i) Competencias relativas al establecimiento y gestión de servicios a la población; j) Competencias relativas a la capacidad de incidir y participar en la gestión de los problemas generales.

104 El Anteproyecto LBGAL trataba de aclarar el régimen de las competencias locales al que dedicaba su Título III, el cual partía de una cláusula general de competencia: «El municipio, para la gestión de sus intereses, tiene competencia en todas las materias no atribuidas expresamente por la legislación del Estado o a las Comunidades Autónomas...» (art. 21). A continuación se establecía un listado de competencias municipales (art. 22) y otro de servicios obligatorios municipales en el que se establecían diferenciaciones en función de la población del municipio (art. 23). Estas previsiones se completaban con la atribución a las municipios de la potestad normativa, en el marco que como mínimo común fijen las normas con rango de ley del Estado y de las CC.AA., en una serie de materias como consumo, cultura, deportes, empleo, educación, sanidad, turismo o vivienda (art. 24). Esta enumeración de materias terminaba con una cláusula «de apertura» que incluía «cualquier otra materia de competencia del Estado o de la CA cuya gestión, total o parcial, se considere que deba ser realizada por las entidades locales, en virtud de los principios de subsidiariedad, descentralización y cercanía o proximidad al ciudadano».

Además, el art. 24 fijaba como principios del ejercicio y la atribución de competencias a las entidades locales los de autonomía, autonomía financiera, subsidiariedad y proporcionalidad. Cabe destacar como se definían estos dos últimos. De acuerdo con el principio de subsidiariedad, la atribución de competencias a otro nivel de gobierno debería tener en cuenta la amplitud o naturaleza de la tarea o las necesidades de eficacia o autonomía. El de proporcionalidad implica que la asunción de una competencia por una Administración supralocal debe ser una medida idónea, necesaria y justificada por su adecuación a las importancia de los fines públicos que se pretenden satisfacer con la intervención legislativa.

El Anteproyecto también incorporaba la norma establecida por los Estatutos de autonomía que hemos analizado: cualquier delegación o encomienda de gestión que el Estado o las CC.AA. realicen a las entidades locales deberá ir acompañada de la dotación o el incremento de los medios económicos necesarios para desempeñarlas. El art. 29 dejaba muy claro que «en ningún caso las entidades locales estarán obligadas a asumir la delegación o encomienda si la Ley que las impone no prevé tales medios». 
ra eficaz una determinada competencia, ésta fuera asumida por otra Administración, que bien podría ser la provincia u otro ente local intermedio ${ }^{105}$.

$6^{\circ}$ ) Esta más completa y definida atribución de competencias debería ir acompañada de una regulación más estricta de los instrumentos normativos locales, dejando muy claro que en aquellas materias no atribuidas a otras Administraciones, los municipios han de poder ejercer potestades plenas de regulación, con el único límite de no vulnerar los ámbitos reservados a la ley. En estos casos, las normas reglamentarias de desarrollo que aprueben la administración del Estado o la autonómica tendrán carácter supletorio respecto a las ordenanzas o reglamentos locales. Sería conveniente regular, aunque fuera de manera mínima, los diferentes tipos de normas que pueden surgir de los distintos órganos locales así como el procedimiento a seguir para su aprobación, en el cual debería facilitarse una mayor participación de los vecinos ${ }^{106}$. Además sería conveniente introducir en los procedimientos de elaboración de las leyes sectoriales (estatales o autonómicas) trámites que permitan la consideración de los intereses locales ${ }^{107}$.

7. ${ }^{\circ}$ ) Ninguna de las reformas anteriores tendrá sentido si no se acompaña de la urgente revisión del modelo de financiación de las corporaciones locales. Algo que subrayó un estudio elaborado por una Comisión de expertos y aprobado por el Pleno del Senado el 11 de diciembre de 2007. En dicho estudio se insistió en cuestiones como la vinculación de la financiación a las competencias reales de los municipios o la reducción de las transferencias condicionadas. Éstas han sido en los últimos años un instrumento que ha permitido que las Comunidades Autónomas utilicen a los ayuntamientos como administraciones a través de las cuales prestan determinados servicios ${ }^{108}$. Es necesario, tal y como proclaman los recién aprobados Estatutos de Autonomía, que la transferencia o delegación competencial que se realice a favor de las entidades locales

105 El Libro Blanco concretaba este principio de «diversidad» o «flexibilidad» proponiendo una serie de
criterios que la Ley Básica debería contener para la asunción diferenciada de competencias: declaración formal
del ayuntamiento que trate de asumir la competencia; redacción por el ayuntamiento de una memoria que
acredite su capacidad de gestión; aprobación por el ayuntamiento de la ordenanza o reglamento que regulara
el ejercicio de la competencia, así con de los instrumentos de planificación o de programación necesarios para
el mismo; en determinados casos, las leyes sectoriales podrían condicionar la asunción de determinadas com-
petencias por los ayuntamientos al cumplimiento de requisitos demográficos, de tipología u otros.

106 Uno de los aciertos del Anteproyecto LBGAL era la atención que se prestaba a la potestad normativa de las entidades locales. En primer lugar se concretaban los instrumentos normativos que las mismas pueden aprobar: estatuto local, ordenanzas, presupuestos generales, decretos de organización, instrumentos de planeamiento urbanístico, decretos de organización y de emergencia (art. 31). A continuación se regulaba con detalle los procedimientos de aprobación de dichos instrumentos, distinguiendo entre los que surgían de iniciativas ciudadanas o de los grupos políticos de los procedentes del Consejo de Gobierno (art. 32).

107 En el Libro Blanco se proponían a título de ejemplo el sometimiento del anteproyecto a informe de la Comisión Nacional de Administración Local y tramitación de los preceptos competenciales del proyecto de ley ante la Comisión Administraciones Públicas del Congreso (o, eventualmente, de una Comisión de la Administraciones Locales del Senado), sin perjuicio de que el grueso del proyecto se sustancie ante la comisión parlamentaria competente por razón de materia.

108 Francisco VELASCO, «El estado de la autonomía local en 2007», cit. Pág. 39. 
se acompañe de los recursos económicos y personales que permitan hacerles frente y en los casos de transferencia de competencias deberían suministrarse recursos de naturaleza incondicionada ${ }^{109}$.

En esta materia es necesario tener presente dos elementos. Por una parte, la necesidad de integrar la financiación de las entidades locales en un sistema que contemple las necesidades financieras de las distintas entidades territoriales. De lo contrario, difícilmente podremos hablar de adecuada garantía de la autonomía local, la cual quedará condicionada por la negociación Estado-Comunidades Autónomas y muy especialmente por la voluntad política de éstas. Por ello, habría que avanzar en el objetivo de conseguir un sistema de financiación que integrara a los distintos niveles territoriales y en cuya negociación, por supuesto, deberían intervenir las entidades locales. De otra parte, dicho sistema debería atender a las dimensiones de cada municipio, teniendo muy presente el papel que habrían de cumplir en la prestación de determinados servicios las entidades intermunicipales. En definitiva, el sistema de financiación debería responder fielmente al principio de solidaridad que la Constitución reconoce como uno de los principios rectores de nuestro modelo territorial.

Además de superar las subvenciones condicionadas, debería regularse de una vez por todas su participación en los tributos de las CC.AA. (PICAs). Algo que la FEMP ha venido denunciado de manera permanente en los últimos años y que afecta a la garantía del principio de suficiencia financiera de las Entidades locales. La regulación estatal de las PICAs deberá hacerse en el nuevo modelo de financiación local, lo que exigirá una reforma de la actual Ley de Haciendas Locales y una modificación menor de la Ley Orgánica de Financiación de las Comunidades Autónomas (LOFCA) ${ }^{110}$.

109 El Anteproyecto LBGAL, al regular el principio de suficiencia financiera, dejaba muy claro que «las transferencias que se reconozcan a las entidades locales por otras Administraciones Públicas tendrán carácter incondicionado, no siéndoles de aplicación la Ley 38/2003, de 17 de noviembre, General de Subvenciones». Ahora bien, a continuación dejaba abierta una posibilidad que puede justificar todo lo contrario: «Éstas sólo podrán establecer subvenciones finalistas cuando circunstancias excepcionales o de interés general, debidamente motivadas, así lo requieran».

110 El legislador no ha extraído todas las consecuencias derivadas del artículo 142 de la Constitución, pues si bien se han desarrollado desde la Ley Reguladora de las Haciendas Locales los tributos propios de las Haciendas Locales y su participación en los ingresos del Estado, «las PICAs únicamente han sido mencionadas, como recurso posible, en la legislación estatal, sin que hasta el momento dispongan de un régimen jurídico que garantice la implicación de las CC.AA. en la financiación de las Corporaciones locales cuyas funciones contribuyen, sin embargo, a delimitar». Ello ha contribuido a mantener el déficit de financiación de los servicios prestados por las Entidades Locales en materias de la competencia autonómica; «fácil de constatar si se observa que, en la práctica, casi todas las CC.AA. han delegado competencias a las Entidades locales o bien se benefician de su colaboración para ejercer las propias, generando los denominados «gastos de suplencia», cuya financiación rara vez se encuentra adecuadamente garantizada» En este sentido, afirma que el Estado dispone de títulos competenciales suficientes para realizar una regulación básica del régimen de las PICAs, estableciendo así un «mínimo común denominador normativo» en relación a este recurso financiero que haga viable su posterior desarrollo y dotación financiera por parte de las CC.AA.

Son las conclusiones de un dictamen coordinado por el Catedrático de Derecho Financiero y Tributario de la Universidad Carlos III de Madrid Juan Zornosa Pérez (noticia consultada en www.femp.es/noticias el 4-11-2008). 
Por otra parte, la financiación local debería tener presentes las grandes diferencias intermunicipales tanto en las bases imponibles de los tributos municipales - la denominada «capacidad fiscal»- como en las necesidades de gasto de los servicios locales. Estas diferencias se traducen irremediablemente en diferencias de calidad en los servicios locales. Para subsanarlas, sería conveniente que las transferencias que reciben los municipios se distribuyan de forma directamente proporcional a las necesidades de gasto de los municipios e inversamente proporcional a su capacidad fiscal ${ }^{111}$. De esta manera, recibirían más recursos los municipios con menor capacidad fiscal y con unas mayores necesidades de gasto. En este sentido habría que tener también presente una realidad cada vez con mayor peso en nuestras ciudades. Me refiero a la creciente movilidad de los ciudadanos que hace que estos se desplacen a lugares distintos a su lugar de residencia por motivos de trabajo, estudios o gestiones de muy diverso tipo. Ello provoca que esos ciudadanos utilicen servicios públicos no sólo en su municipio de residencia sino también en aquel al que se desplazan ${ }^{112}$. De ahí que el sistema de financiación debería tener en cuenta no sólo el número de residentes sino también, sobre todo en los municipios que sean los principales «receptores» de esa movilidad, las necesidades que plantea prestar determinados servicios en función del número de personas que cotidianamente los utilizan, con independencia de su lugar de origen o residencia.

8..$^{\circ}$ Esta cuestión nos llevaría a su vez a la necesidad de regular de manera más completa y eficiente las relaciones intergubernamentales. En este sentido, además de consolidar y reforzar la Conferencia Sectorial para Asuntos Locales, cabría plantear la presencia de las entidades locales en el Senado así como en otros órganos como el Consejo de Política Fiscal y Financiera o en las Conferencias Sectoriales del Estado ${ }^{113}$. Como ha reiterado buena parte de la doctrina, cabría también convertir la Comisión de Entidades Locales del Senado en una Comisión permanente de carácter legislativo que, entre otras cuestio-

\footnotetext{
111 Albert SOLÉ OLLÉ, «Economía política de los gobiernos locales. Una valoración del funcionamiento de los municipios», Actualidad, n. ${ }^{\circ}$ 15, 2007. Centro de Estudios Andaluces, pág. 13. En este mismo trabajo se mantiene que el sistema tributario municipal debe continuar basándose en los mismos pilares: tasas y precios públicos, IBI y un nuevo impuesto de negocios de debería sustituir a los actuales restos del IAE. Albert SOLÉ propone que en el caso de que se transfieran nuevas competencias - por ejemplo, en educación - y que se quieran financiar de forma descentralizada debería considerarse la posibilidad de transferir capacidad normativa en el IRPF a los municipios, al estilo del modelo nórdico, ibidem, pág. 19.

112 Albert SOLÉ OLLÉ, «Economía política de los gobiernos locales...», cit., págs. 11-13.

113 El Pleno del Senado aprobó el 17-9-08 una moción basada en un texto del Grupo Popular, y apoyada por todos los grupos salvo el socialista, por la que instaba al gobierno a crear «urgentemente» un órgano para la defensa de los intereses económicos de los Ayuntamientos, el denominado Consejo de Política Financiera Local. Al mismo tiempo se le instaba a una reforma de la financiación municipal en paralelo a la reforma de la autonómica y a incrementar la participación local en los ingresos del ejercicio 2009. En la moción se proponía que el Consejo de Política Financiera Local estuviese integrado por representantes de la FEMP, de las principales asociaciones municipales de ámbito autonómico, de los seis mayores municipios del Estado y de una representación de municipios pequeños y medianos. Este órgano se reuniría al menos trimestralmente con la Administración General del Estado para tratar cuestiones como la actualización del catastro, las transferencias estatales, la gestión de convenios o la cooperación administrativa.
} 
nes, debería informar todos los proyectos legislativos y acuerdos que afecten a las entidades locales. Igualmente habría que modificar las funciones de la Comisión Nacional de Administración Local para que realmente coordine las políticas legislativa y presupuestaria del Estado con las entidades locales ${ }^{114}$.

En definitiva, las necesarias reformas aún pendientes en nuestro régimen local inciden en su anclaje en un sistema de distribución del poder apoyado en tres ámbitos territoriales y guiado por el principio de solidaridad. Si no asumimos estos restos de manera urgente, el carácter político de la autonomía local seguirá siendo una mera declaración formal y los municipios y provincias continuarán siendo «convidados de piedra» en un proceso descentralizador que continúa resistiéndose a reconocer el papel fundamental de las ciudades en el desarrollo político, económico y social del Estado. Esas «pequeñas repúblicas», como las denominó Jefferson, en las que se forja nuestra memoria, la individual y la colectiva, y en las que construimos nuestra identidad como ciudadanos. Argumentos más que suficientes para reclamar el lugar que se merecen en el edificio constitucional.

114 Este es una de las cuestiones a las que más y mejor atención prestaba el Anteproyecto LBGAL. En concreto, dedicaba un capítulo entero a la «cooperación interadministrativa». En él concreta que la designación de los representantes de las entidades locales en la Comisión Nacional de Administración Local corresponderá a la FEMP (art. 36.2). Las competencias de esta Comisión se redactan de manera mucho más genérica: informar los anteproyectos de ley, los proyectos de disposiciones administrativas generales estatales, los acuerdos de naturaleza económico-financiera que afecten a los gobiernos locales, la emisión de informe previo en el supuesto de acuerdo de disolución de las Corporaciones locales, así como efectuar propuestas al Gobierno de la Nación en materia de gobierno y administración local (art. 36.2). Se prevía también una Conferencia de Asuntos Urbanos, integrada por las ciudades con más de 250.000 habitantes (art. 37); una Conferencia General de Política Local, que vendría a sustituir a la Conferencia Sectorial para Asuntos locales, como «máximo órgano de cooperación para la articulación de las relaciones entre la Administración General del Estado, de las CC.AA. y de los gobiernos locales» (art. 38), o un Observatorio urbano de la calidad de vida en los municipios con población superior a 75.000 habitantes o capitales de provincia, adscrito al Ministerio de Administraciones Públicas (art. 41).

El Anteproyecto incluía la obligatoriedad de que las Entidades locales, por medio de representantes designados por la FEMP, formasen parte de las Conferencias sectoriales (art. 39). Además se ordenaba al Gobierno adoptar las medidas necesarias para hacer efectiva la participación de las entidades locales, también a través de la FEMP, en la formación de la voluntad nacional en la fase ascendente del proceso de elaboración de todas aquellas políticas comunitarias que afecten de manera directa a las competencias locales (art. 43).

El art. 45 preveía la participación de las entidades locales en los procesos estatales y autonómicos de planificación, programación y proyección sobre todas las cuestiones que les afecten directamente, y en especial en los ámbitos de las obras públicas, infraestructuras, equipamientos y servicios públicos, a fin de permitir la armonización de los intereses públicos afectados. En todo caso, el legislador continuaba otorgando un relevante papel de coordinación al Gobierno de la Nación o al Consejo de Gobierno de la Comunidad Autónoma, «con la finalidad de asegurar la coherencia de la actuación de las Administraciones Públicas, cuando las actividades o los servicios locales trasciendan el interés propio de las correspondientes entidades, incidan o condicionen relevantemente los de dichas Administraciones o sean concurrentes o complementarios de los de éstas, y siempre que aquella finalidad no pueda cumplirse a través de los mecanismos fijados en los artículos anteriores o resulten manifiestamente inadecuados por razón de las características de la tarea pública de que se trate» (art. 47). La «peligrosa» vaguedad de esta previsión trataba de contrarrestarse con la fijación de la autonomía de las entidades locales como límite a las funciones de coordinación (art. 47.5). 